\title{
The fossil record of turtles and tortoises (Testudines) of Mexico, Central America and the Caribbean Islands, with comments on its taxonomy and paleobiogeography: a bibliographic review
}

\section{Gerardo Carbot-Chanona ${ }^{1,2, *}$, Gustavo Rivera-Velázquez ${ }^{3}$, Eduardo Jiménez-Hidalgo ${ }^{4}$, and Víctor Hugo Reynoso ${ }^{5}$}

\author{
${ }^{1}$ Museo de Paleontología "Eliseo Palacios Aguilera”, Departamento de Paleontología, \\ Secretaría de Medio Ambiente e Historia Natural, Calzada de Las Personas Ilustres, s/n, C.P. 29000, \\ Tuxtla Gutiérrez, Chiapas, Mexico. \\ ${ }^{2}$ Doctorado en Ciencias en Biodiversidad y Conservación de Ecosistemas Tropicales, \\ Instituto de Ciencias Biológicas, Universidad de Ciencias y Artes de Chiapas, \\ Libramiento Norte Poniente 1150, Colonia Lajas Maciel, C.P. 29039, Tuxtla Gutiérrez, Chiapas, Mexico. \\ ${ }^{3}$ Laboratorio de Acuacultura y Evaluación Pesquera, Instituto de Ciencias Biológicas, \\ Universidad de Ciencias y Artes de Chiapas. Libramiento Norte Poniente 1150, \\ Colonia Lajas Maciel, C.P. 29039, Tuxtla Gutiérrez, Chiapas, Mexico. \\ ${ }^{4}$ Laboratorio de Paleobiología, Instituto de Recursos, Campus Puerto Escondido, \\ Universidad del Mar, km 2.5 Carretera Puerto Escondido-Sola de Vega, \\ C.P. 71980, Puerto Escondido, Oaxaca, Mexico. \\ ${ }^{5}$ Colección Nacional de Anfibios y Reptiles, Departamento de Zoología, Instituto de Biología, \\ Universidad Nacional Autónoma de México. Circuito Exterior, Ciudad Universitaria, \\ Coyoacán, Mexico City, C.P. 04510, Mexico. \\ *gfcarbot@gmail.com
}

\section{ABSTRACT}

Testudines is the crown-group that includes all living forms of turtles and their closest extinct relatives. This group is known to exist starting in the Middle Jurassic. The fossil record of Testudines in Mexico is scarce but has been previously compiled in several papers. In this paper, we are presenting an update that includes all osteological and ichnological records of Mexico, and we have added fossil records of turtles and tortoises from Central America and the Caribbean Islands. In Mexico, the Testudines fossil record extends from the Late Jurassic to the Pleistocene, and widely abundant during the late Pleistocene. Kinosternon and Gopherus are the best represented taxa, known from the late Miocene to the late Pleistocene. In Mexico, records of fossil turtles show a wide distribution, except in the areas around the states of Campeche and Quintana Roo in the east; Colima, Guerrero, and Sinaloa in the west, and Querétaro, and Mexico City in the center. Ichnological records are known only in Coahuila, Puebla and Zacatecas. Reports of fossil turtles in Central America include El Salvador, Honduras, Costa Rica, Nicaragua and Panama--the latter being the country with the most records--and in the Caribbean Islands including Cuba, Dominican Republic, Jamaica, the United States islands of Puerto Rico and Navassa, and the British Island of Sombrero in Anguilla. Seven fossil turtles have been described as new species in Mexico (Notoemys tlaxiacoensis, Yelmochelys rosarioae, Mexichelys coahuilaensis, Allaeochelys liliae, Gopherus donlaloi, G. auffenbergi and G. pargensis, of which G. auffenbergi is synonymous with G. berlandieri, and G. pargensis is considered a nomen vanum); two from Panama (Rhinoclemmys panamaensis and Staurotypus moschus); one from Costa Rica (Rhinoclemmys nicoyama); two from Cuba (Notoemys oxfordensis and Chelonoidis cubensis); one from the Dominican Republic (Chelonoidis marcanoi), one from Puerto Rico (Chelonoidis monensis), and one from Sombrero Island, Anguilla (Chelonoidis sombrerensis).

Key words: Cryptodira; Pleurodira; Mesozoic; Paleogene; Neogene; Cenozoic; Mexico; Central America.

\section{RESUMEN}

Testudines se refiere al grupo-corona que incluye a todas las formas de tortugas vivientes y sus ancestros más cercanos. Este grupo apareció en el Jurásico Medio. El registro fósil de Testudines en México es escaso y ha sido previamente compilado en diversos escritos. Aqui se presenta una recopilación actualizada, con las evidencias osteológicas e icnológicas de México, además del registro de tortugas fósiles de América Central y las islas del Caribe. En México, el registro fósil de Testudines abarca desde el Jurásico Tardío hasta el Pleistoceno tardio, siendo más abundantes en esta última época. Kinosternon y Gopherus son los taxones mejor representados y se conocen desde el Mioceno tardío hasta el Pleistoceno tardío. En México, las tortugas fósiles tienen una distribución muy amplia, excluyendo solamente los estados de Campeche, Ciudad de México, Colima, Guerrero, Querétaro, Quintana Roo y Sinaloa; y los registros icnológicos

Carbot-Chanona, G., Rivera-Velázquez, G., Jiménez-Hidalgo, E., Reynoso, V.H., 2020, The fossil record of turtles and tortoises (Testudines) of Mexico, Central America and the Caribbean Islands, with comments on its taxonomy and paleobiogeography: a bibliographic review: Revista Mexicana de Ciencias Geológicas, v. 37, núm. 3, p. 269-283. 
solamente existen en Coahuila, Puebla y Zacatecas. En América Central existen reportes de tortugas fósiles en El Salvador, Honduras, Costa Rica, Nicaragua y Panamá, siendo este último el país con más registros; $y$ en las islas del Caribe incluye Cuba, República Dominicana, Jamaica, las islas de Puerto Rico y Navassa, ambos territorios estadounidenses y la isla británica de Sombrero en Anguila. Siete especies fósiles se han descrito como nuevas en México (Notoemys tlaxiacoensis, Yelmochelys rosarioae, Mexichelys coahuilaensis, Allaeochelys liliae, Gopherus donlaloi, G. auffenbergi y G. pargensis, de las cuales G. auffenbergi se sinonimizó con $G$. berlandieri y $G$. pargensis es considerado un nomen vanum), dos en Panamá (Rhinoclemmys panamaensis y Staurotypus moschus) y una en Costa Rica (Rhinoclemmys nicoyama), dos en Cuba (Notoemys oxfordensis and Chelonoidis cubensis); una en República Dominicana (Chelonoidis marcanoi), una en Puerto Rico (Chelonoidis monensis) y una en la Isla Sombrero, Anguila (Chelonoidis sombrerensis).

Palabras clave: Cryptodira; Pleurodira; Mesozoico; Paleógeno; Neógeno; Cenozoico; México; América Central.

\section{INTRODUCTION}

Testudines refers to the crown-group that includes all forms of living and fossil turtles and their closest relatives (Joyce et al., 2004). Morphological and molecular studies show that turtles are diapsids closely related to Archosauromorpha (Rieppel and deBraga, 1996; Crawford et al., 2012; Field et al., 2014; Shaffer et al., 2017), and not anapsid sauropsids as previously thought. Basal forms (Testudinata), are mainly known for the Late Triassic and Early Jurassic (Broin, 1984; Gaffney, 1990; Gaffney and Kitching, 1994, 1995; Li et al., 2008; Szczygielski and Sulej, 2016; Joyce, 2017), the true turtles (Testudines) appeared by the Middle Jurassic (Joyce, 2017), and since then the lineage has survive and evolved worldwide.

The Testudines fossil record in Mexico, Central America and the Caribbean Islands is scarce. Mexican turtle fossil fauna has been previously compiled in several works. The first known compilation was the unpublished undergraduate thesis of Barrios Rivera (1985), who elaborated the most extensive review of Mexican fossil vertebrates until then. This compendium has been the base of all following reappraisals. Flores-Villela (1993) when analyzing the herpetofauna of Mexico summarizes the fossil records of amphibians and reptiles from the Eocene to the Pleistocene in a table; however, he does not specify exact locations or bibliographic sources. The most complete published review of fossil turtles was that of Reynoso (2006), who compiled research on fossil reptiles in Mexico until then. In that publication he mentioned 89 fossil turtle records from the Late Cretaceous to the Pleistocene, located all over Mexico. Later, Chávez Galván et al. (2013) created a synopsis of Quaternary Mexican herpetofauna extracted from paleontological and archeological sites; and most recently Brinkman (2014) compiled Mesozoic turtles of Mexico particularly focused on reports from the Cerro del Pueblo and Cañón del Tule formations in Coahuila, and the Cabullona Group in Sonora, but left out several turtle records reported in other locations. However, the Central American and Caribbean Islands fossil record of turtles has been left aside and has only been partially summarized by Cadena et al. (2012) and Albury et al. (2018).

To understand the patterns of temporal and spatial distribution of this group in the northern hemisphere, here we present a detailed compilation of fossil turtles in Mexico, Central America and the Caribbean Islands, including the ichnological record, previously ignored in former compilations. Once this information is available, we will have an updated overview of the raw paleobiodiversity of fossil turtles in the region.

\section{METHOD}

We conducted a detailed and extensive review of Mexican, Central America, and the Caribbean Islands fossil turtle literature and lists (e.g. Barrios Rivera, 1985; Flores-Villela, 1993; Reynoso, 2006; Cadena et al., 2012; Chávez Galván et al., 2013; Albury et al., 2018), supplemented by recent reports in scientific literature, book chapters, and some grey literature as well as thesis and abstracts at academic meetings. When several publications refer to the same taxa in the same locality, we used the original source, in order to avoid data redundancy. Additionally, we consulted Mexican and Central American Paleontological Collections to obtain specimen records not reported in the literature. Generic and specific names were used as they were first published and the validity of some assignments is discussed in the related section.

In the catalog we used the traditional definition of a fossil, which are the remains of organisms that lived in the geological past, older than 10000 years (Buitrón et al., 2010). Because of this, reports from some islands in the Caribbean Islands dated as late Holocene were not included.

\section{RECORDS BY COUNTRY AND GEOLOGICAL AGE}

A total of 86 localities with fossil record of turtles and tortoises were found for Mexico, Central America and Caribbean Islands (Figure 1). Of these localities, 59 are in Mexico, 12 in Central America and 15 in the Caribbean Islands. In Mexico we found one Jurassic, 12 Cretaceous, one Eocene, three Oligocene, six Miocene, five Pliocene and 31 Pleistocene localities. In El Salvador, there are three localities of the Pleistocene, in Honduras and Costa Rica one of the Miocene and one of the Pleistocene each; in Nicaragua one Pleistocene, and in Panama one Oligoene and three Miocene localities.

In Mexico, Central America and Caribbean Islands, 22 families -of which ten are extinct- have been found. The highest diversity at the family level is from the Mesozoic with 14 families recorded.

Many of the fossils mentioned in specialized literature only have been identified at the family or generic level, while many other specimens have not been adequately described, and others have not been illustrated. This is caused by the lack of knowledge of turtles themselves or because the difficulty in assigning partial bone elements to more specific taxa.

\section{Costa Rica}

\section{Paleogene}

The first turtle record in Costa Rica was Testudo costarricensis from Peralta de Limón, Cartago Province (Segura, 1944), dated as Oligocene-Miocene or Eocene age. Currently, this record is considered invalid (Lichtig et al., 2018).

\section{Neogene}

Remains of Apalone sp. (Figure 2a) from the El Limoncito (Late Miocene) were reported from the west of San Vito, Canton de Coto Brus, Puntarenas Province (Laurito et al., 2005), where still unidentified turtle remains have been recovered recently (Laurito, 2017, com. pers.).

\section{Quaternary}

Rhinoclemmys nicoyama (Figure 2b) was described by AcunaMesén and Laurito-Mora (1996) based on a nuchal bone and plastral elements collected from the riverbed of the Nacaome River in Barra Honda, Nicoya (Late Pleistocene), Guanacaste Province. 


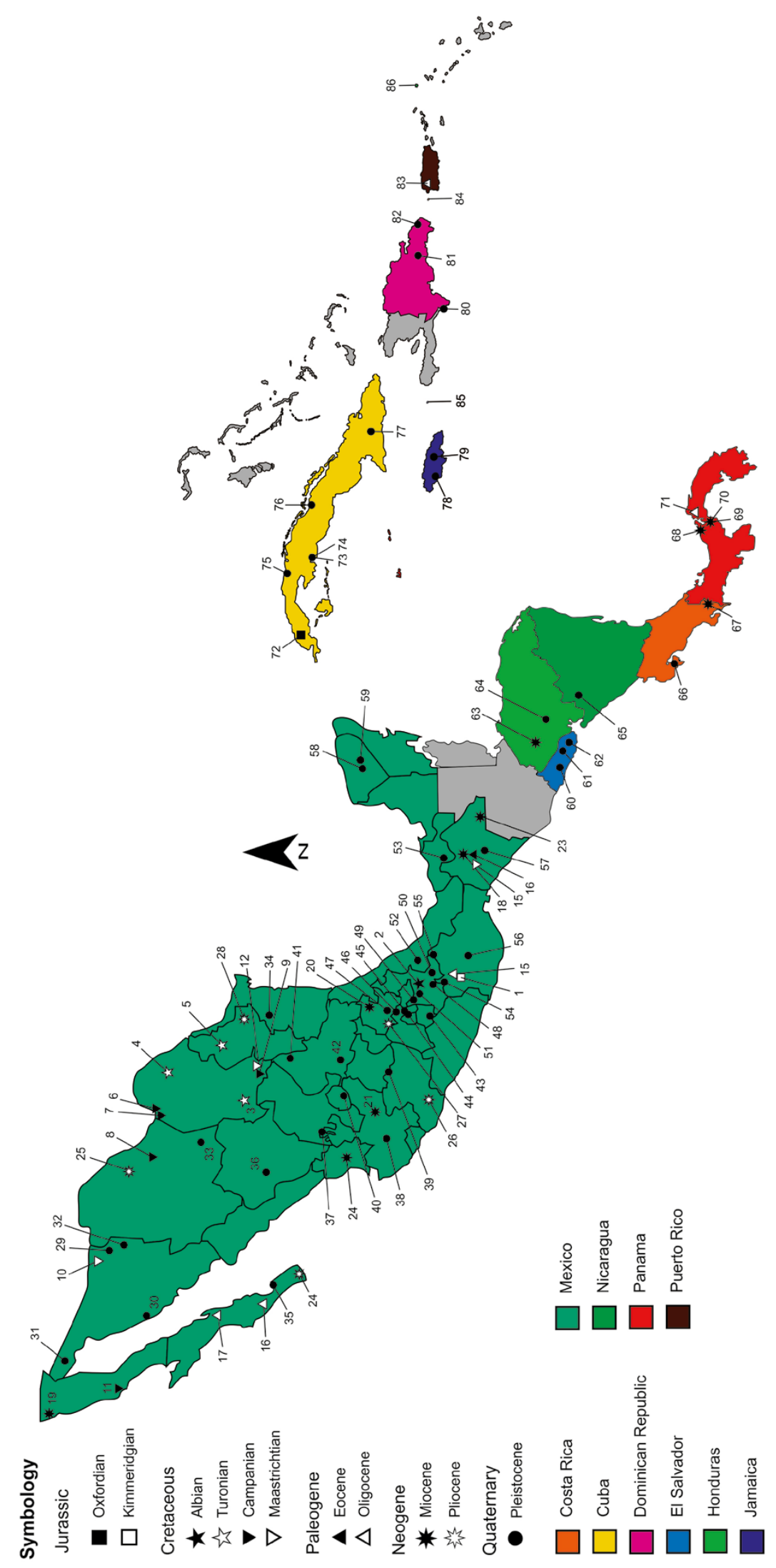

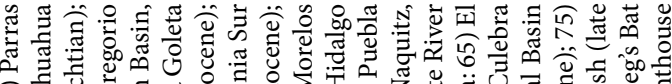

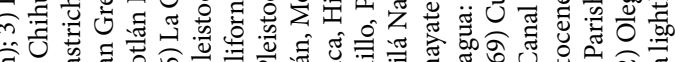

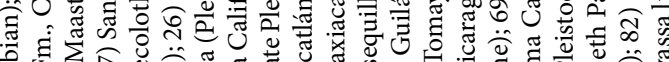

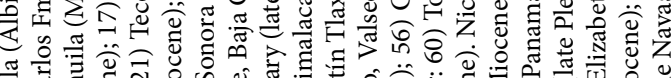

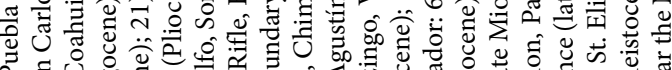

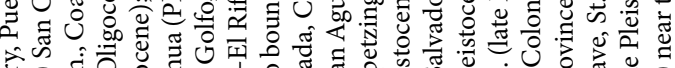

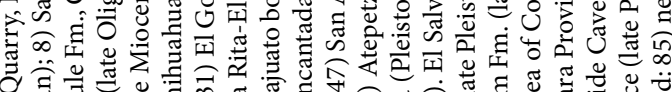

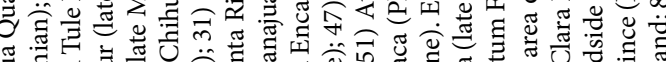

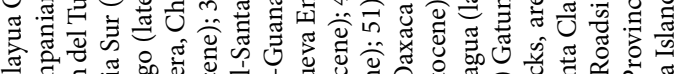

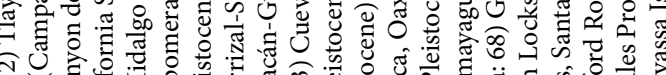

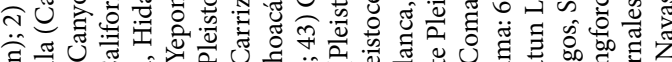

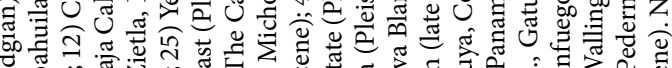

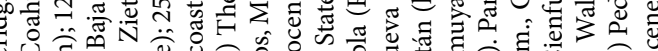

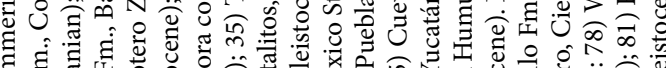

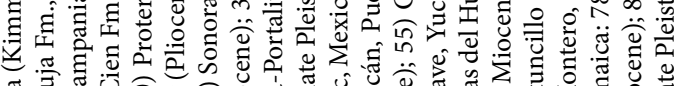

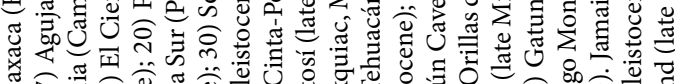
ơ

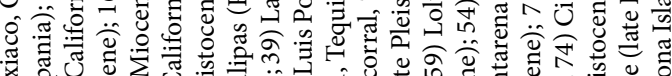

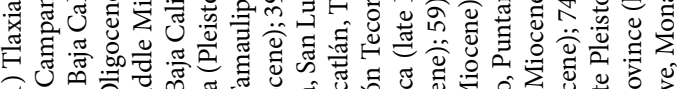

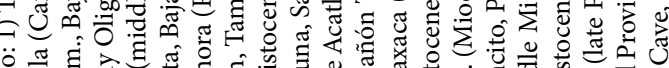

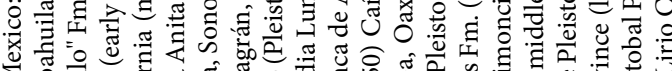

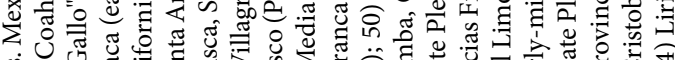

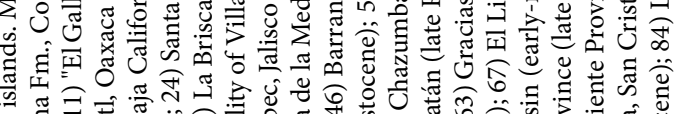

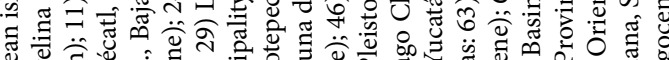

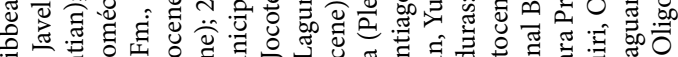

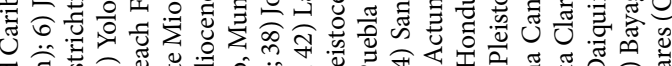

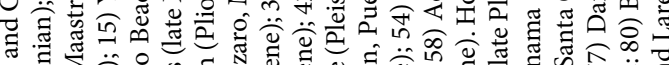

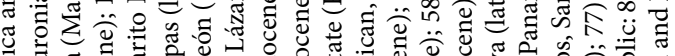

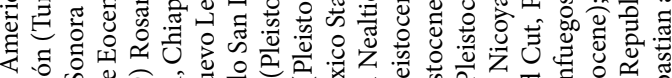
留

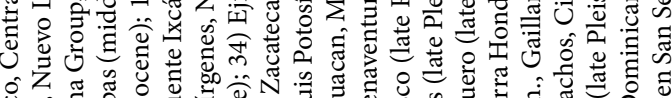
o $\begin{aligned} & 0 \\ & 0 \\ & 0\end{aligned}$

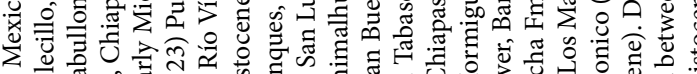
曰零

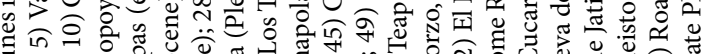

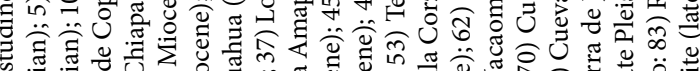

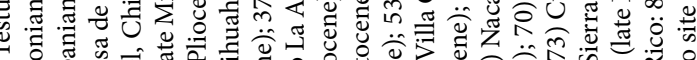

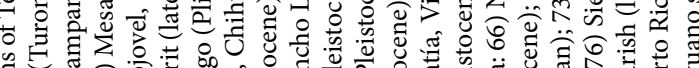

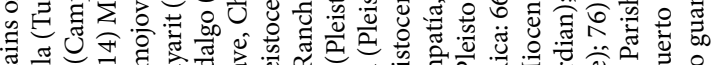

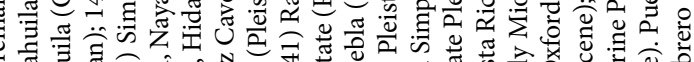

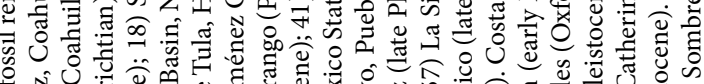

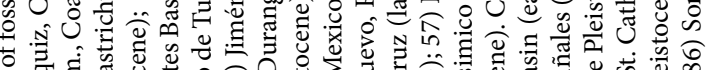

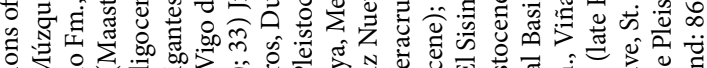
을

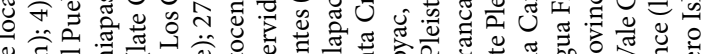

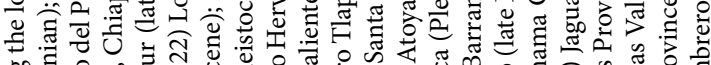
on 0 o

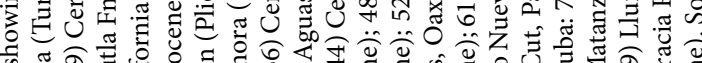

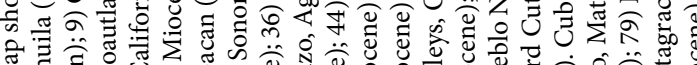

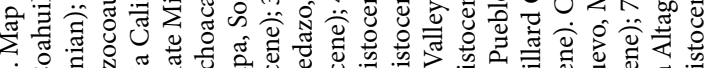

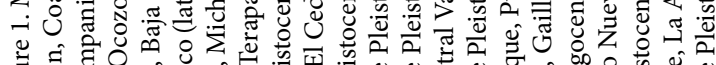

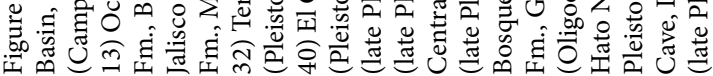




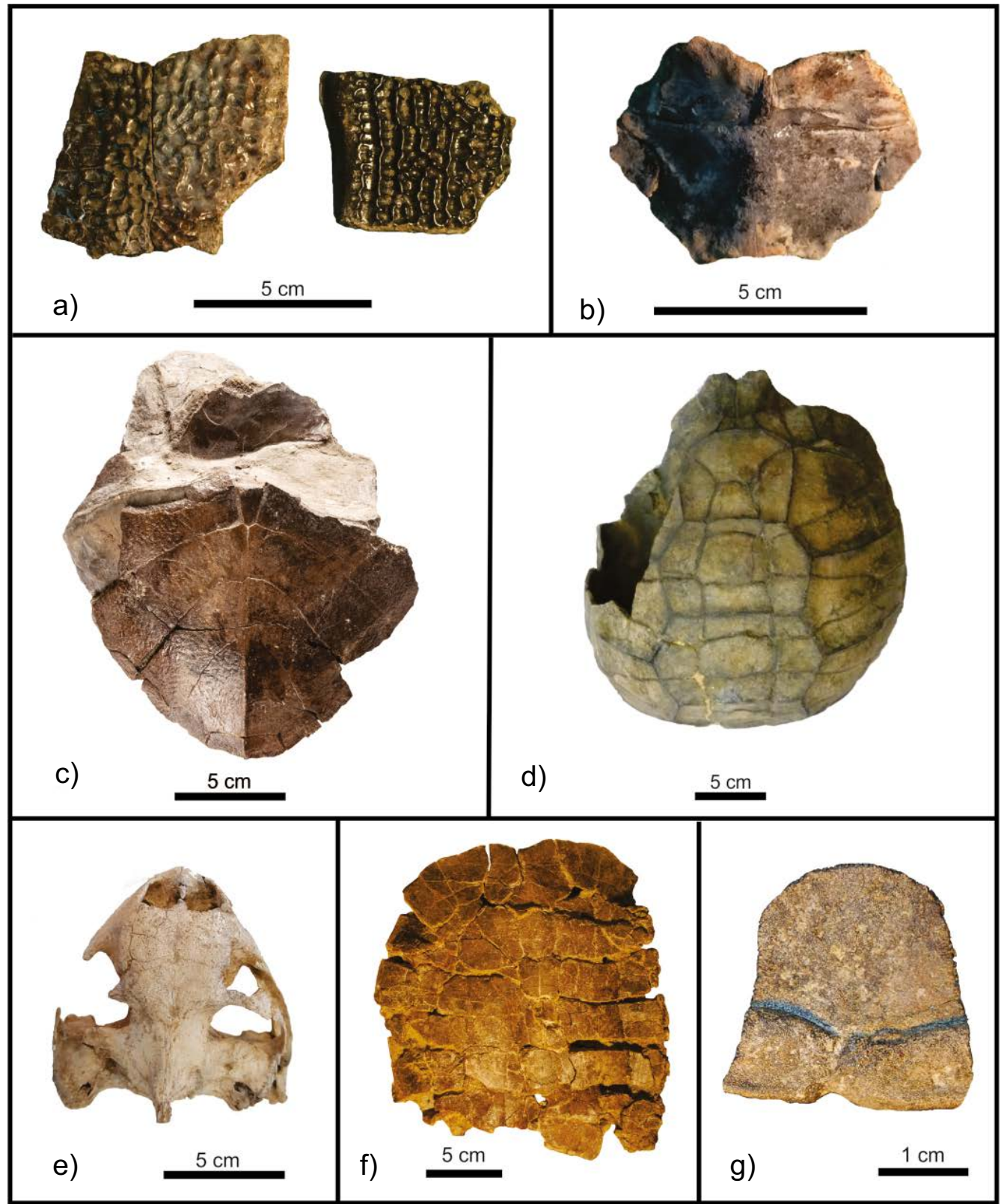

Figure 2. Neogene Testudines from Mexico and Central America. a) Apalone sp., El Limoncito (late Miocene), Costa Rica; b) Rhinoclemmys nicoyama, nuchal (holotype CFM 1311), Barra Honda Nicoya, Costa Rica; c) Allaeochelys liliae (holotype MALM-401), Los Pocitos mines, Simojovel, State of Chiapas, Mexico; d) Gopherus berlandieri (=G. auffenberger) from the early Pleistocene of Aguascalientes; e) Gopherus donlaloi (holotype, IGM 6076), skull in dorsal view, late Pleistocene, Tamaulipas; f) Rhinoclemmys panamaensis, carapace in dorsal view (holotype UF 237887), Cucaracha Formation (early Miocene), Panama; g) Staurotypus moschus, left peripheral (holotype UF 242076), Cucaracha Formation (early Miocene), Panama.

Cuba

\section{Jurassic}

The marine turtle Caribemys oxfordiensis was described based on a nearly complete shell recovered in the Jagua Formation (Upper Jurassic, Oxfordian), near of Viñales, Pinar del Río Province (De la Fuente and Iturralde-Vinent, 2001). Later, Cadena Rueda and Gaffney (2005) reassigned the species to Notoemys.

\section{Neogene}

Unidentified Pelomedusoides turtle has been reported from
Lagunitas Formation (early Miocene) in Domo de Zaza, Sacti Spiritus Province (MacPhee et al., 2003.).

\section{Quaternary}

Testudo cubensis was described by Leidy (1868) based on a costal plate. It was found together with the lower jaw of a giant sloth at Ciego Montero, Cienfuegos Province. Additional material (plates and a femur) assigned to T. cubensis came from a tar pit near Hato Nuevo, Matanzas Province (Williams, 1950). Also, several remains referred to Pseudemys cf. P. decussata were recovered from Sierra de Jatibonico, and Ciego Montero localities, and fragments of plastral and carapace 
assigned just to Pseudemys were recovered from Daiquiri, Oriente Province, and Cueva de los Machos near Cienfuegos, Santa Clara Province (Williams, 1950).

\section{Dominican Republic}

\section{Quaternary}

The first record of large tortoises in Dominican Republic was documented based on shell fragments and limb elements collected at a cave near Bayaguana in San Cristobal Province, in the Los Haitises region, and referred to Geochelone (Franz and Woods, 1983). Chelonoidis marcanoi was described based on several remains, making up at least seven individuals from Quaternary sediments at several cave sites in Pedernales Province, southern Dominican Republic (Turvey et al., 2017). Also, Chelonoidis dominicensis, was described based on one specimen that conserved the skull, the shell nearly complete, and appendicular skeleton recovered from the Oleg's Bat Cave in La Altagracia Province, southeastern Dominican Republic (Albury et al., 2018).

\section{El Salvador}

\section{Quaternary}

Hesperotestudo crassiscutata, Kinosternon sp. and an unidentified Emydidae were recovered from the Tomayate river (Middle-late Pleistocene) (Cisneros, 2005). Hesperotestudo (=Geochelone) was also reported at Barranca del Sisimico locality (Early-Middle Pleistocene), San Vicente Department, and El Hormiguero locality (late Pleistocene), San Miguel Department (Webb and Perrigo, 1984).

\section{Honduras}

\section{Neogene}

Rhinoclemmys sp. and Geochelone sp. were recovered from the Gracias Formation (Late Miocene), near the Gracias town in the Department of Lempira. Rhinoclemmys is known from an isolated nuchal bone that combines diagnostic morphological features for the genus: narrow anteromedian scute, strong midsagittal keel, and strong posteromedian concavity (Webb and Perrigo, 1984). Geochelone based on one large shell and several shell fragments, however, diagnostic features have been not provided (Webb and Perrigo, 1984).

\section{Quaternary}

Rhinoclemmys sp. was recovered from Orillas del Humuya (Late Pleistocene), Comayagua Department, in association with the toxodon Mixotoxodon larensis, the ground sloths Eremotherium sp. and Megalonyx sp., the mammoth Mammuthus columbi, the horse Equus sp., and the capybara Hydrochoerus sp. (Webb and Perrigo, 1984).

\section{Jamaica}

\section{Quaternary}

Several fossil remains referred to Pseudemys terrapen have been recovered from Late Pleistocene deposits at Wallingford Roadside Cave, in St. Elizabeth Parish, and from Lluidas Vale Cave, St. Catherine Parish (Williams, 1950).

\section{Mexico}

\section{Mesozoic}

Late Jurassic. Notoemys tlaxiacoensis (Platychelyidae) comprises the oldest turtle record in Mexico described from partial shell, pre- serving part of the carapace and plastron (Figure 3a) from Sabinal Formation (Kimmeridgian) of Yosobé, Tlaxiaco, Oaxaca (López-Conde et al., 2016).

Cretaceous. We know of Cretaceous fossil turtles in Baja California, Chiapas, Coahuila, Chihuahua, Puebla, Nuevo León and Sonora (see Figure 1). In the Early Cretaceous the turtle record is represented by tracks assigned to the ichnogenus Emydhipus found in the San Juan Raya Formation (lower Aptian) in Santa Ana Teloxtoc, Tehuacán, Puebla (Rodríguez-de la Rosa et al., 2017). The ichnofossil found was associated with traces of marine invertebrates, crocodyliforms, pterosaurs and non-avian dinosaurs. Two specimens referred to Araripemydidae (Pleurodira, Pelomedusoides) (García and ReynosoRosales, 2006), as well as other specimens not yet determined (Figure 3e; Reynoso et al., 2000) are known from the Tlayúa Quarry (Albian), Puebla.

In the Late Cretaceous Trionyx sp. was reported by José Aguilera (1869), from the Division Parras, Parras, Coahuila (early Turonian). This report is the first known record of a fossil turtle for Mexico. Two protostegids, Desmatochelys lowii, and an undescribed form possibly belonging to a new taxon were reported from the Eagle Ford Formation (Turonian) from Múzquiz, Coahuila (Delgadillo-Escobar and Rodríguez-de la Rosa, 2011; Rodríguez-de la Rosa et al., 2011). Two unidentified turtle specimens were reported from Agua Nueva Formation (Turonian), in Vallecillo, Nuevo León (Blanco et al., 2001). One of these specimens is believed to be a Desmatochelys (Figure 3b). For the Coniacian there is a single report of turtle tracks in the sandstone of the Caracol Formation, exposed on the wall of an abandoned mine located between the municipalities of Mazapil and Concepción del Oro, Zacatecas (González-Romo et al., 2012; Figure 4a). Another protostegid specimen, referred as Desmatochelys cf. D. lowii, from the San Carlos quarry (Austin Formation, Campanian) was recently described (López-Conde et al., 2019; Figure 3d). This specimen preserves both articulated hindlimbs, elements not described before in D. lowii (López-Conde et al., 2019). Many fossil turtles have been reported at Cerro del Pueblo Formation, Coahuila (Campanian). From this formation Toxochelys latiremis, Yelmochelys rosarioae, Euclastes coahuilaensis (Figure 3c), Chedighaii sp., Bothremys sp., Compsemys sp. Neurankylus sp., Adocus sp., Hoplochelys sp. have been reported, as well as unidentified specimens referred to Chelydridae, Pleurosternidae, Adocidae and Trionychidae (Rodríguez-de la Rosa and Cevallos-Ferriz, 1998; García and Reynoso-Rosales, 2002; Brinkman and Rodríguez-de la Rosa, 2006; Brinkman et al., 2009; Rivera-Sylva et al., 2011; Rodríguez-de la Rosa et al., 2011; Brinkman et al., 2016). On this locality, turtle tracks not related to any known ichnogenus and associated with theropod and pterosaur (Pteraichnus) footprints were also reported in El Pelillal, Coahuila (Rodríguez-de la Rosa, 2003; Figure 4b). Naomichelys was reported for the "El Gallo" Formation in Baja California (Late Campanian) based on costal bone and plastron fragments that showed typical cylindrical tubers ornamentation (Rodríguez-de la Rosa and Aranda-Manteca, 2000). Additional taxa have been recently described at this Formation by López-Conde et al. (2018) that includes Compsemys victa and Basilemys sp., as well as fragment specimens referred to Trionychidae indeterminate and cf. Chelydridae. The first known turtle icnofossil record was reported at the Cañón del Tule Formation (Campanian), in the Ramos Arizpe municipality, Coahuila (Rodríguez-de la Rosa and Dávila-Rodríguez, 1998). Additional remains referred to Trionychidae have been found in Aguja Formation (Late Campanian), Javelina Formation (Maastrichtian) and San Carlos Formation (CoanacianMaastrichtian), on the border between Chihuahua and Coahuila; and in the Corral de Enmedio Formation and Packard Formation, Cabullona Group (Late Campanian-Maastrichtian) in Sonora (Lucas et al., 1995; 


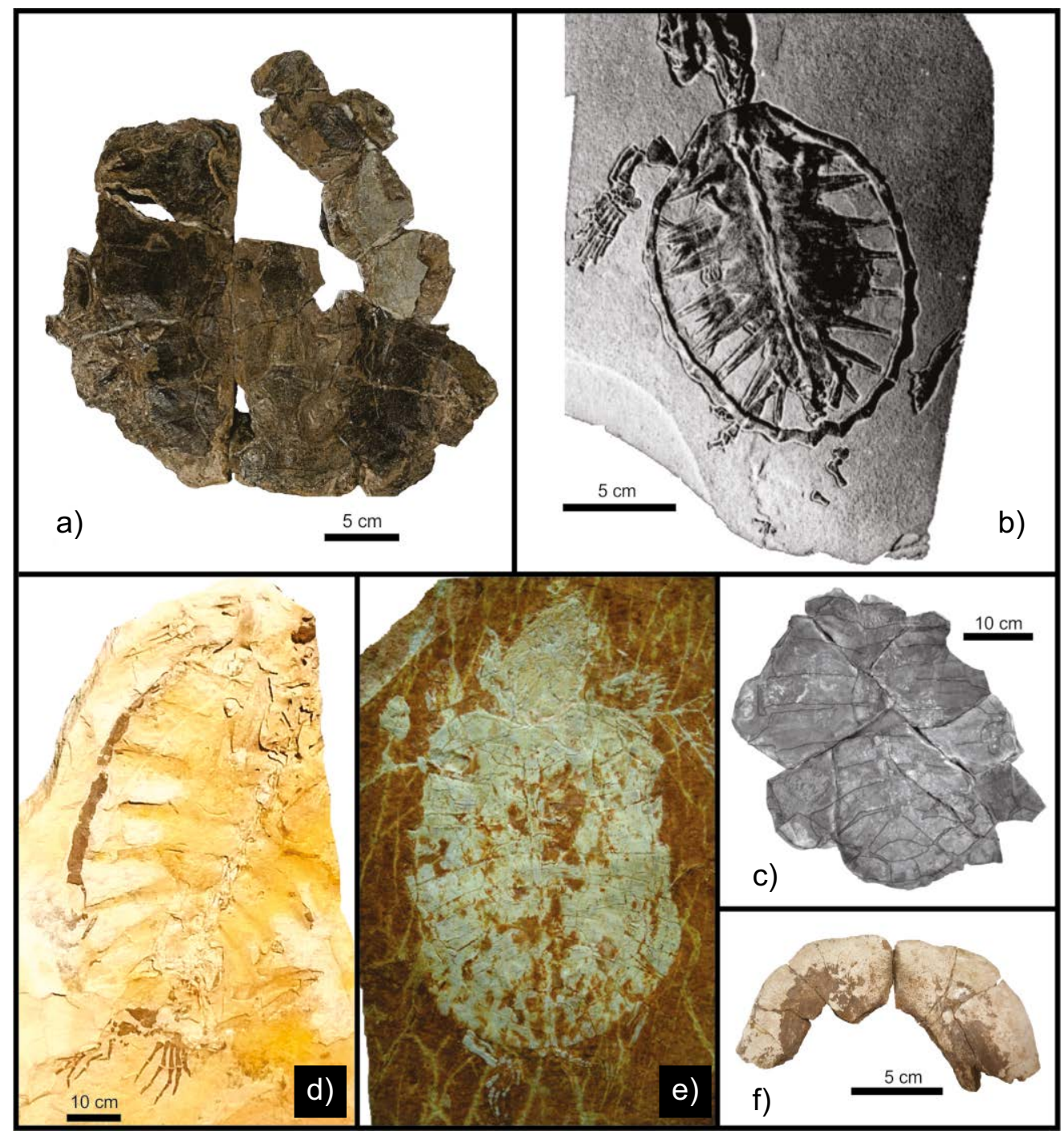

Figure 3. Mesozoic Testudines from Mexico. a) Notoemys tlaxiacoensis, carapace in dorsal view (holotype IGM 4861), Sabinal Formation (Kimmeridgian, Late Jurassic), Oaxaca; b) Desmatochelys sp., Vallecillo (Upper Cretaceous, Turonian), Nuevo León (taken from Blanco et al., 2001); c) Mexichelys coahuilaensis, carapace in dorsal view (paratype CPC 259), La Parrita, Cerro del Pueblo Formation (Upper Cretaceous, Campanian), Coahuila (taken from Brinkman, 2014); d) Desmatochelys cf. D. lowii, specimen in ventral view (MUZ-562), Austin Formation (Campanian) Jiménez, Coahuila; e) Araripemydidae indeterminate, Tlayúa Quarry (Early Cretaceous, Albian), Puebla; f) plastron fragment of the undetermined turtle in ventral view, Ocozocoautla Formation (Upper Cretaceous, Maastrichtian), Chiapas.

Brinkman, 2014). Hoplochelys sp., the species Yelmochelys rosarioae and Trionychidae are also known for Cañón del Tule Formation, Coahuila (Maastrichtian) (Brinkman and Rodríguez-de la Rosa, 2006; Brinkman et al., 2016). In Southern Mexico, about seven carapace and plastron fragments and one femur from the Ocozocoautla Formation (Maastrichtian) have been reported (Figure 3f); however, the specimens have not been studied in detail and therefore their taxonomic identity is still unknown (Carbot-Chanona and Ovalles-Damián, 2013).

\section{Paleogene}

Eocene. A poorly preserved shell from the Mesa de Copoya (Middle Eocene), southwest of Tuxtla Gutiérrez, Chiapas, was reported by Mullerried (1943); currently, this material is lost.

Oligocene. Sea turtles associated with bony fishes, sharks, rays, dolphins, desmostilids and whales were reported in the El Cien Formation and in the central area of the San Gregorio Formation (Late Oligocene, Chattian) in San Juan de la Costa and La Purísima area, Baja California
Sur (González Barba and Alvarado Ortega, 2009). Aff. Hadrianus sp. and Stylemys sp. were reported as part of the Iniyoo Local Fauna, near Santiago Yolomécatl, northwest Oaxaca (Jiménez-Hidalgo et al., 2015), recently dated as early Oligocene (Guerrero-Arenas et al., 2020).

\section{Neogene}

Miocene. A new species of the family Carettochelyidae, Allaeochelys liliae (Figure 2c; Carbot-Chanona et al., 2020) from a single specimen recovered from the amber mines in the Simojovel (Mazantic Shale, lower Miocene) is known. Dermochelys, Mesochelonia and Syllomus have been reported from Rosarito Beach Formation (middle Miocene) (Aranda Manteca, 2013). Pseudemys sp. and Kinosternon sp. were reported in Potrero Zietla (late Miocene), Hidalgo (Castillo Cerón et al., 1996). Isolated carapace and plastron plates assigned to Testudinidae and Trionychidae were collected in a sequence of lacustrine sediments from the Tecolotlán Basin, Jalisco (late Miocene, Hemphillian) (Aguilar Cabrera et al., 2013). Gopherus, from Tecolotlán Basin was 
also reported, but the exact locality where the specimen was found is not known (McDonald and Carranza-Castañeda, 2017). A shell referred to as cf. Trachemys sp. was collected at San Nicolás Formation, San Luis Potosí (late middle to late Miocene; Ferrusquía-Villafranca et al., 2014). Turtle shell remains, possibly belonging to Geochelone were found in Los Gigantes Basin (late Miocene), in Nayarit (CarranzaCastañeda, 2006). Remains of turtles assigned to Dermatemydidae and Trionychidae were recovered in Puente Ixcán (late Miocene) in Marqués de Comillas, Chiapas (Carbot-Chanona, 2011).

Pliocene. Geochelone sp. was recovered from Las Tunas, in Santa Anita, Los Cabos, Baja California (Miller, 1980); Gopherus berlandieri from El Fronton locality, Atotonilco, Hidalgo (Nájera Hernández, 2006); cf. Gopherus sp. from Yepomera, Chihuahua (Brattstrom, 1961); Gopherus or Hesperotestudo from San José de Pimas, La Colorada, Sonora (White et al., 2010); and Testudo sp., and Kinosternon sp. from La Goleta, Michoacán (Brattstrom, 1955). Kinosternon sp. from La Viga de Tula, Hidalgo (Castillo Cerón et al., 1996) was also reported. Brattstrom (1961) reported an unidentified turtle from Río Vírgenes Village [sic], in Nuevo León.

\section{Quaternary}

Pleistocene. The turtle fossil record in the Pleistocene is the most abundant and diverse. Kinosternon and Gopherus are the genus with the most records. For Kinosternon, K. scorpioides was reported from Los Tanques, Zacatecas (Guzmán and Polaco, 1998); Arroyo Cedazo, Aguascalientes (Mooser, 1980); Cueva Encantada, Chimalacatlán, Morelos (Arroyo-Cabrales et al., 2004) and La Simpatía, Villa Corzo, Chiapas (Luna-Espinosa and Carbot-Chanona, 2009); K. integrum from Guilá Naquitz, Valles Centrales, Oaxaca (Flannery and Wheeler, 1986) and Jocotepec, Jalisco (Barrios Rivera, 1985); K. cf. integrum from Los Tanques, Zacatecas (Guzmán and Polaco, 2000); K. hirtipes from Jocotepec, Jalisco (Barrios Rivera, 1985); K. hirtipes/integrum from Santiago Chazumba, Oaxaca (Cruz et al., 2009); K. flavescens and $K$. sonoriense from La Brisca, Sonora (Van Devender et al., 1985); K. cf. cruentanum/creaseri for Actun Xpukil cave system, Yucatán (Barrios Rivera, 1985). Kinosternon sp. has been reported from Chihuahua (Chacón-Soria and Aguilar, 2010; White et al., 2010); Los Tanques, Zacatecas (Guzmán and Polaco, 1998, 2000); Rancho La Amapola and Laguna de la Media Luna, San Luis Potosí (Hernández Junquera, 1977; Lorenzo and Mirambell, 1986); La Cinta-Portalitos, in the Michoacán-Guanajuato boundary (Moreno-Flores et al., 2017); Cueva Encantada, Chimalacatlán, Morelos (Arroyo-Cabrales et al., 2004); Cerro Tlapacoya, Estado de México (Álvarez and Huerta, 1975); Potrero Zietla local fauna, Hidalgo (Castillo Cerón et al., 1996; López et al., 2002), and Santa Cruz Nuevo, Puebla (Tovar and Montellano, 2006; Tovar et al., 2007), and cf. Kinosternon sp. in Chimalhuacán, Estado de México (Barrios Rivera, 1985). Gopherus, G. agassizii from the Sonora coast was reported (Moodie and Van Devender, 1979); the new species G. auffenbergi (Figure 2d) from El Cedazo, Aguascalientes (Mooser, 1972); G. berlandieri from the Cañón Tecorral, in Tehuacán, Puebla; Actopan, Epazoyucan, and San Agustín Tlaxiaca, in Hidalgo (Nájera Hernández, 2006; Castillo-Cerón et al., 2009) and Cueva Blanca, Santa María Chilchotla, in Oaxaca (Flannery, 1967;); Gopherus cf. G. berlandieri from Santa Cruz Nuevo, Puebla (Tovar and Montellano, 2006; Tovar et al., 2007), G. donlaloi (Figure 2e) was described as a new species from Ejido San Lázaro, Villagrán, Tamaulipas (Reynoso and Montellano-Ballesteros, 2004); G. flavomarginatus for the Cedazo local fauna, Aguascalientes; Cerro Hervideros, Durango and Los Tanques, Zacatecas (Mooser, 1980; Guzmán and Polaco, 1998, 2000); Gopherus cf. G. flavomarginatus from Jiménez Cave, Chihuahua (Messing, 1986); G. pargensis was described as a new species from El Cedazo, Aguascalientes (Mooser, 1980), and Gopherus sp. from El Carrizal-

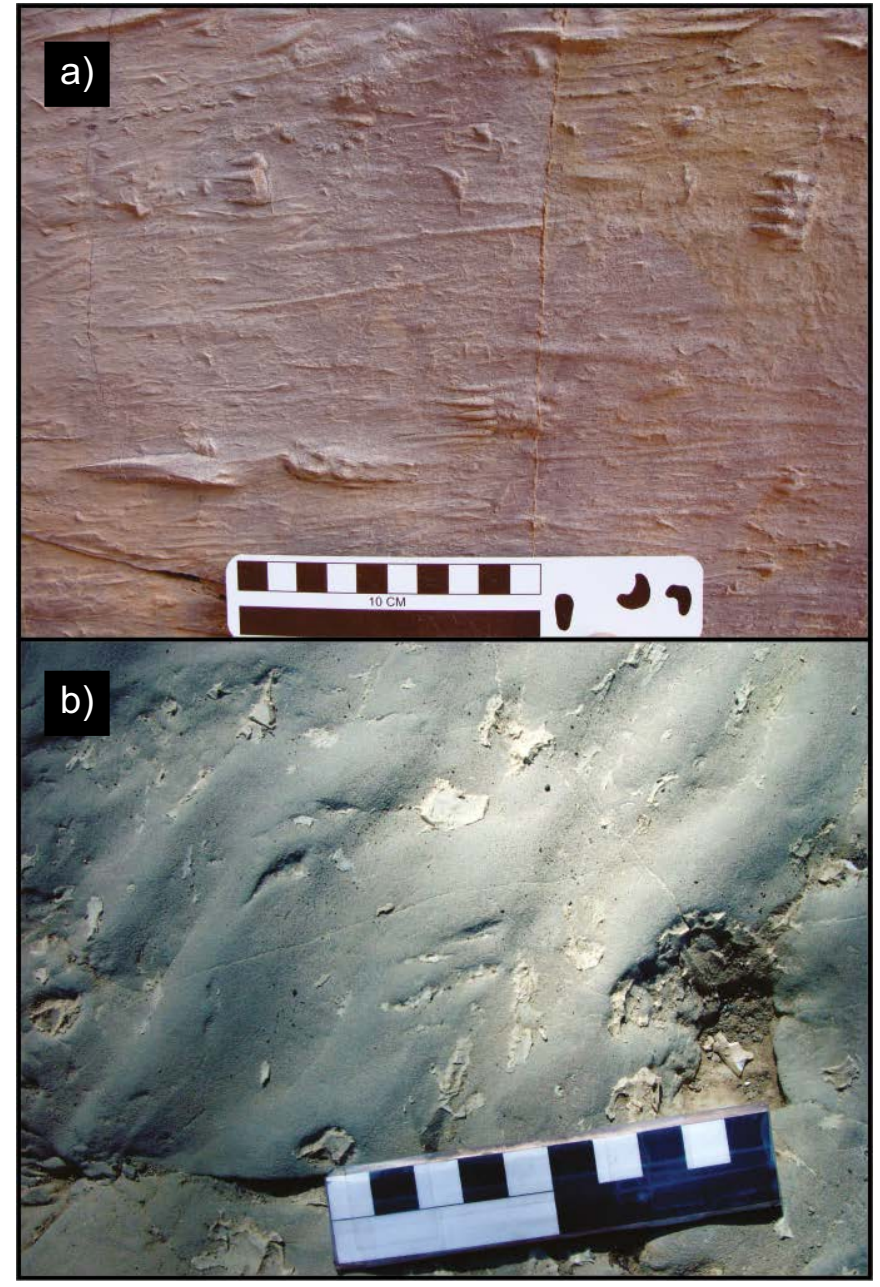

Figure 4. Cretaceous turtle footprints from Mexico. a) Impressions of anterior and posterior extremities found in the Caracol Formation (Late Cretaceous, Coniacian), north of Zacatecas. b) Partial impression of a turtle footprint found in the Cerro del Pueblo Formation (Late Cretaceous, Campanian), Coahuila.

Santa Rita-El Rifle area, Baja California Sur (Ferrusquía-Villafranca and Torres-Roldán, 1980); San Agustín Tlaxiaca, Hidalgo (Bravo-Cuevas, 2001); Santiago Chazumba, Oaxaca (Cruz et al., 2009); Pitiquito and Hermosillo, Sonora (White et al., 2010), and La Cinta-Portalitos, in the Michoacán-Guanajuato boundary (Moreno-Flores et al., 2017).

Trachemys is another turtle with a good number of records in Pleistocene sediments from Mexico. Trachemys scripta has been reported in Atoyac, Veracruz (Peña-Serrano and Miranda-Flores, 2006), and La Simpatía, Villa Corzo municipality, Chiapas (Luna-Espinoza and Carbot-Chanona, 2009). Trachemys sp. have records in Los Tanques, Zacatecas (Guzmán and Polaco, 2000); San Buenaventura Nealtican, Puebla (Herrera-Flores, 2009) and Loltún cave, Yucatán (Cruz et al., 2016).

Other taxa that have been reported are Claudius angustatus for Atoyac, Veracruz (Peña-Serrano and Miranda-Flores, 2006); Chelonia sp. in Baja California Sur (González-Barba et al., 1998); Terrapene culturatus in Jocotepec, Jalisco (Barrios Rivera, 1985); cf. Terrapene sp. from Rancho La Brisca, Sonora (Van Devender et al., 1985); Geochelone sp. in Potrero Zietla local fauna, Hidalgo (Nájera Hernández and Castillo Cerón, 2004), El Cedazo, Aguascalientes (Mooser, 1980) and El Golfo, Sonora (Barrios Rivera, 1985); Hesperotestudo sp. in Puerto 
Peñasco and La Colorada, Sonora (White et al., 2010) and Epazoyucan, Hidalgo (Castillo-Cerón et al., 2009); Testudo sp. in El Cedazo, Aguascalientes (Mooser, 1958); Barranca de Acatlán, Tequixquiac, Estado de México (Hibbard, 1955) and Atepetzingo, Valsequillo, Puebla (Güenther, 1968); cf. Staurotypus sp. in La Simpatía, Villa Corzo, Chiapas (Luna-Espinosa and Carbot-Chanona, 2009); Rhinoclemmys sp. in Santa Cruz Nuevo, Puebla (Tovar and Montellano, 2006; Tovar et al., 2007); Chrysemys scripta in El Golfo, Sonora (Barrios Rivera, 1985); Pseudemys scripta for the Rancho La Brisca locality, in Sonora (Van Devender et al., 1985) and Pseudemys sp. in Jocotepec, Jalisco and Teapa, Tabasco (Polaco-Ramos, 1981; Barrios Rivera, 1985), as well as Chelydridae and Trionychidae in Térapa, Sonora (Moscato and Jasinski, 2016).

\section{Navassa Island, United States of America}

\section{Quaternary}

Auffenberg (1967) reported several fragments remains of turtles and tortoises recovered from brecciated deposit at the top of a sink hole near the Navassa lighthouse that he referred to as Geochelone and Pseudemys.

\section{Nicaragua}

\section{Quaternary}

At El Bosque locality (Pleistocene), southwest of Pueblo Nuevo, Estelí Department, a turtle and a tortoise were documented, associated to megatheriid and megalonychid ground sloth, gomphotheres, horses, deer and toxodonts (Lucas et al., 2008).

\section{Panama}

\section{Paleogene}

Podocnemididae is known for the Gatuncillo site, Gatuncillo Formation (Late Eocene-Early Oligocene), Colón Province (Cadena et al., 2012).

\section{Neogene}

Testudinidae and Podocnemididae were recovered from the Culebra Formation (early Miocene), while Rhinoclemmys panamaensis (Figure 2f), Rhinoclemmys sp., Staurotypus moschus (Figure 2g), Testudinidae, Trionychidae and Podocnemididae were recorded in Cucaracha Formation (early Miocene), Centenario Bridge, in the Panama Canal basin, and Cheloniidae from the Gatum Formation (late Miocene) (Cadena et al., 2012).

\section{Puerto Rico}

\section{Paleogene}

A fragmentary pelomedusid shell was described by Wood (1972) and assigned to Oligocene age. The specimen apparently comes from an uncertain locality along the highway between San Sebastian and Lares municipalities.

\section{Quaternary}

Testudo (Monachelys) monensis was described based on cranial, postcranial and appendicular remains from Lirio Cave, in Mona Island (Williams, 1952).

\section{Sombrero Island, Anguilla}

The only evidence of tortoise or turtles in the Sombrero Island is Emys sombrerensis, that was named based on plastron and carapace remains recovered at Sombrero guano, a site rich in lime phosphate (Leidy, 1868). Additional material of this taxon was described by Julien (1878) and Auffenberg (1967).

\section{DISCUSSION}

\section{Taxonomy}

Today, 13 genera and two ichnogenera have been identified for the Mesozoic of Mexico, including three new species: Notoemys tlaxiacoensis, Yelmochelys rosarioae and Euclastes coahuilaensis (Brinkman et al., 2009; Brinkman et al., 2016; López-Conde et al., 2016). Of these taxa, only the taxonomic status of E. coahuilaensis has changed, since Parham and Pyenson (2010), based on the results of their cladistic analyzes, found that E. coahuilaensis is separated from the Cenozoic species Euclastes wielandi and E. platyops, for which they erected the name Mexichelys, to include the species coahuilaensis.

Trionyx is another taxon reported for the Cretaceous of Coahuila (Aguilera, 1869). Meylan (1987) mentioned that Trionyx has served as a "garbage basket" since there has been a tendency to synonymize Trionychidae with the generic name. Today, Trionyx is considered a genus restricted to Africa and Asia (Rhodin et al., 2017) and it is not expected to be present in the American Continent. Then, the specimen described by Aguilera (1869), should be referred to Trionychidae. Similarly, the specimen determined as Bothremys sp. from the Cerro del Pueblo Formation, Coahuila (García and Reynoso-Rosales, 2002) was tentatively referred to as Chedighaii by Gaffney et al. (2006). However, the new taxonomic assignment was based on photographs of the specimens but it was not possible to observe diagnostic features that differentiate Bothremys from Chedighaii, such as the presence/ absence of holes in the crushing surface of the maxilla-jugal (Gaffney et al., 2006). Recent work on the specimen by García and Reynoso (in prep.) suggests that the specimen may represent a new genus and species of Bothremydidae.

Among Cenozoic turtles, Pseudemys, Chrysemys and Trachemys have been reported at several Pleistocene localities. Reynoso (2006) pointed out that the fossils reported in Mexico as Pseudemys and Chrysemys are in fact Trachemys. Molecular studies show that Pseudemys, Chrysemys and Trachemys are distinct valid genera (Wiens et al., 2010; Guillon et al., 2012). As it is considered today, Pseudemys and Chrysemys are restricted to Canada and the US, but these taxa do not extend their distribution far south into Mexico. To have a proper species assignment in the Mexican fossils it is necessary to review in detail the morphology of the known material. Trachemys remains from Atoyac, Veracruz (Peña-Serrano and Miranda-Flores, 2006) and La Simpatía, Chiapas (Luna-Espinoza and Carbot-Chanona, 2009) were referred to T. scripta. Historically, Trachemys scripta was divided into several subspecies, but recently those subspecies were elevated to the rank of species (Fritz et al., 2012). So, Trachemys scripta's distribution ranges from the southeastern part of the US, to as far south as northern Nuevo León, Mexico. The species from Atoyac can be easily assigned to T. venusta, based on distribution, but the remains from La Simpatía, Chiapas may be referred either to T. grayi or T. venusta which overlap distribution in Chiapas (Fritz et al., 2012; Rhodin et al., 2017). However, remains need to yield good diagnostic features in order to be reassigned to particular taxa. In the absence of diagnostic morphological characters in fossil specimens of both Veracruz and Chiapas, we recommended naming these specimens only at the genus level, Trachemys sp. as suggested by Reynoso (2006). Likewise, Pseudemys terrapen from Jamaica and Pseudemys cf. P. decussata from Cuba (Williams, 1950), should be referred to Trachemys, as indicated by Morgan (1993). 
Terrapene culturatus reported in Jocotepec, Jalisco referred by Barrios Rivera (1985) is not a valid name since this species has never been described. Based on the recent distribution of Terrapene in Mexico (Rhodin et al., 2017), we believe it is possible that records of Jocotepec in Jalisco, and Rancho La Brisca in Sonora, may belong to Terrapene nelsoni.

A recent review of the specimens referred as cf. Hadrianus sp. and Stylemys sp. from the Oligocene Iniyoo Local Fauna, Oaxaca (JiménezHidalgo et al., 2015), show that these specimens should be referred to as a different taxon (Carbot-Chanona et al., work in progress).

Gopherus is a taxonomically complicated genus that includes six extant and seven extinct species (Edwards et al., 2016, Rhodin et al., 2017; Vlachos, 2018). Bramble (1982) synonymized the Irvingtonian G. auffenbergi of El Cedazo in Aguascalientes (Mooser, 1972), with G. berlandieri. Similarly, Gopherus pargensis (Mooser, 1980) was considered invalid because the species was described based on a shell fragment with no diagnostic morphological characters (Reynoso and Montellano-Ballesteros, 2004). However, Vlachos (2018) considered G. pargensis a junior synonymous of G. auffenbergi, because both species share the singular costal morphology that characterizes G. auffenbergi.

Meylan (1995) argued that all North American fossil forms referred to Geochelone should be called Hesperotestudo, since Geochelone is a restricted genus for India, Pakistan, Sri Lanka and Myanmar (Rhodin et al., 2017). Meylan (1995) also suggested that small size Hesperotestudo should be referred to subgenus Hesperotestudo and large size ones to Caudochelys. Then Geochelone sp. from Las Tunas fauna in Baja California Sur, El Golfo in Sonora, El Cedazo in Aguascalientes, Atotonilco in Hidalgo, the Gracias Formation in Honduras, and Barranca del Sisimico and El Hormiguero in El Salvador (Miller, 1980; Mooser, 1980; Barrios Rivera, 1985; Webb and Perrigo, 1984; Nájera Hernández and Castillo Cerón, 2004), should be referred to as Hesperotestudo. The specimens from Tomayate river in El Salvador referred to as Hesperotestudo crassiscutata (Cisneros, 2005), must be updated, as this taxon has only been reported in Pleistocene deposits from Florida, Georgia and Texas (Meylan, 1995; Hulbert and Pratt, 1998; Powell et al., 2016).

Testudo is another genus distributed only in southern Europe, northern Africa and Middle East (Rhodin et al., 2017). Then, the specimens reported for Pleistocene localities of El Cedazo in Aguascalientes, Barranca de Acatlán in Estado de Mexico, and Atepetzingo in Puebla (Hibbard, 1955; Mooser, 1958; Güenther, 1968) and for the Pliocene locality La Goleta Formation in Michoacán (Brattstrom, 1955) should belong either to Gopherus or Hesperotestudo, but material needs to be reviewed.

"Testudo" costarricensis was considered evidence of a migration of tortoises from North America to South America and the antecessor of the genus Chelonoides (Segura, 1944). This taxon was later reclassified as Geochelone costarricensis (Auffenberg, 1971). It was even considered in a phylogenetic analysis (Coto Rojas and Acuña Mesen, 1986), However, "Testudo" costarricensis was based on an incorrect reconstruction of their carapace and plastron, and an reexamination of the holotype by Lichting et al. (2018) shows it to be identical to the tortoise Oligopherus laticuneus from the Oligocene of North America. Vlachos (2018) considers that "Testudo" costarricensis differs from Oligopherus laticuneus in the absence of a contact between marginal VI and pleural III, the rounded anterior plastral lobe, and the overlap of the pectoral scutes on the posterior part of the entoplastron, concluding that $T$. costarricensis should be referred as a different genus other than those named for North America.

The species from the Caribbean Islands, originally assigned to genus Testudo (e.g. T. cubensis and T. monensis), now are considered to belong to genus Chelonoidis (Franz and Franz, 2009).

\section{Spatial and temporal distribution}

In Mexico, turtle remains have been found in 24 states, excluding Campeche, Mexico City, Colima, Guerrero, Querétaro, Quintana Roo and Sinaloa, and only Coahuila, Puebla and Zacatecas have ichnological records. For Central America, there are fossil turtles in El Salvador, Honduras, Costa Rica and Panama (Figure 1). in the Caribbean Islands there are turtle remains in Cuba, Dominican Republic, Jamaica, the United States islands of Puerto Rico and Navassa, and the British Island of Sombrero in Anguilla. The temporal range includes from Late Jurassic to late Pleistocene (Figure 5).

Notoemys seems to be restricted to the American Continent. Four species have been described: N. oxfordiensis from the Jagua Formation (Late Jurassic, Oxfordian), Cuba (de la Fuente and IturraldeVinent, 2001); N. zapatocaensis of the Rosablanca Formation (Lower Cretaceous, Valanginian), Colombia (Cadena and Gaffney, 2005); $N$. laticentralis of the Vaca Muerta Formation, Argentina (Late Jurassic-Early Cretaceous, Tithonian-Berriasian) (Lapparent de Broin et al., 2007; Cadena and Joyce, 2015) and N. tlaxiacoensis of the Sabinal Formation (Late Jurassic, Kimmeridgiano), Mexico (LópezConde et al., 2016). Notoemys extends from the Oxfordian to the Valanginian and it appears to have a wide distribution range within the continent, from Colombia to Argentina (including the Caribbean islands), and $N$. tlaxiacoensis extended the geographic range to North America.

In the Aptian-Albian there are records of Araripemydidae only in central Mexico, and the family seems to be restricted for this interval of time worldwide. Araripemids were first described from gondwanic deposits: Araripemys barretoi from the Santana Formation (Lower Cretaceous, Aptian-Albian) in Brazil (Price, 1973; Meylan, 1996); and, Taquetochelys decorate from the basin of the Ténéré Desert (Lower Cretaceous, Aptian) in Niger (Broin, 1980; Pérez-García, 2019). It is possible that distribution in Mexico would extend its range to North America.

In the Upper Cretaceous of Mexico there are 13 families present: Adocidae, Baenydae, Bothremydidae, Cheloniidae, Chelydridae, Compsemydae, Helochelydridae, Kinosternoidae, Nanhsiungchelyidae, Pleurosternidae, Protostegidae, Solemydae, and Trionychidae. Protostegidae is the only family with records in the Turonian and all other families are present in the Campanian. Cheloniidae and Chelydridae are also known for the Maastrichtian, although these families extend their temporal range to the Recent (Ernst and Barbour, 1989; Meylan and Meylan, 2000). It is likely that the high diversity of families during the late Cretaceous of Mexico corresponds to the extension of the Western Interior Seaway and the predominance of warm global temperatures (Wrigth, 1987; Upchurch et al., 1998), factors that favored emergence of tropical ecosystems, which undoubtedly influenced the diversification of ectothermic sauropsids, such as turtles. In contrast, the few records and low diversity during the Paleocene of Mexico and Central America could be a consequence of the K-Pg extinction, or maybe, due to the little paleontological work has been done in these countries.

During the Neogene Testudines diversity rose again. Trionychidae, Emydidae and Testudinidae became the most extended families with the most records. Trionychidae was well represented from the Turonian to the Maastrichtian in northern Mexico (Aguilera, 1869; Rodríguez-de la Rosa and Cevallos-Ferriz, 1998; Brinkman and Rodríguez-de la Rosa, 2006; Brinkman, 2014; Brinkman et al., 2016). During the Paleogene, Trionychidae has been reported from the Early to the late Miocene, as far north as Jalisco in western Mexico, to Panamá (Aguilar Cabrera et al., 2013; Carbot-Chanona, 2011; Laurito et al., 2005; Cadena et al., 2012). The distribution of Trionychidae today extends as far north as in Mexican states bordering the United States (Legler and Vogt, 2013; 


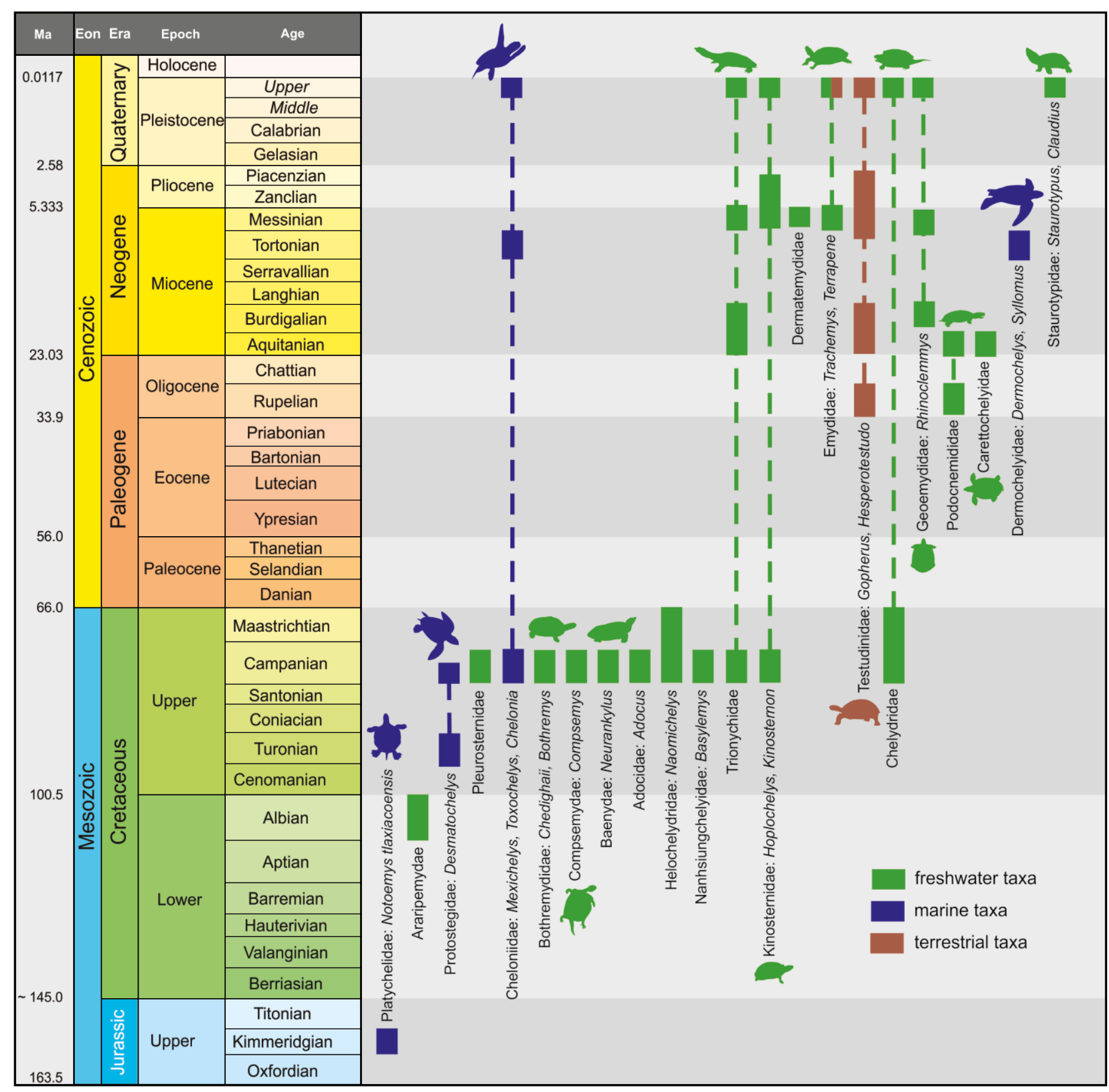

Figure 5. Geochronological range of Testudines families present in the fossil record of Mexico and Central America. Silhouettes drawn by Gerardo Carbot-Chanona.

Rhodin et al., 2017), suggesting that the family went extinct in north central Mexico and Central America after the Miocene.

The fossil record of Testudinidae appears by the end of Paleogene in Mexico, consistent with those of the United States; however, in Central America this family appears by the early Neogene, and in the Caribbean Islands in the Pleistocene, but today, this family is extinct in these islands. The greatest diversity of Testudinidae in Mexico and Central America occurred from the late Miocene to the late Pleistocene. Today, only Gopherus is restricted to North America, extending as far south as southern Tamaulipas and Durango, while only Chelonoidis is present in Central America (south of Panama) (Rhodin et al., 2017).
The extension of the distribution range of the Testudinidae species was possibly favored by the cooling during the Eocene-Oligocene transition (Liu et al., 2009) with environmental conditions that prevailed until the Pleistocene. Hesperotestudo has been reported from central Mexico to Costa Rica, but this genus faced extinction in the Pleistocene. Conversely, the genus Gopherus that was very successful from the Miocene, still survives with five living species, of which G. berlandieri, G. evgoodei, G. flavomarginatus and G. morafkai are distributed in northern Mexico (Rhodin et al., 2017). Gopherus agas$s i z z i$ was reported for the Sonoran coast (Pleistocene) (Moodie and Van Devender, 1979), although currently this area is occupied by $G$. 
morafkai (Murphy et al., 2011). The original taxonomic assignation to G. agassizii was done considering that at the time, G. agassizii was the only species considered for western North America. According to recent Gopherus species distribution in the area, it is more probable that the turtle of Moodie and Van Devender (1979) belongs to $G$. morafkae, but a detailed review of the material should be done before drawing final conclusions.

Fossil remains assigned to Gopherus sp. are known farther south from current distribution area. The genus has been reported from Baja California Sur, the border between Michoacán and Guanajuato and Estado de Mexico (Ferrusquía-Villafranca and Torres-Roldán, 1980, Moreno-Flores et al., 2017), and as far south as Oaxaca (Cruz et al., 2009). Gopherus flavomarginatus, is currently distributed in southeastern Chihuahua, southwest of Coahuila and north of Durango (Ernst and Barbour, 1989), but in the late Pleistocene it extended its distribution south to Aguascalientes and Zacatecas (Mooser, 1980; Guzmán and Polaco, 1998, 2000). Gopherus berlandieri is found in eastern Coahuila, Nuevo León to southern Tamaulipas and San Luis Potosí (Ernst and Barbour, 1989; Rhodin et al., 2017), but during the late Pleistocene it extended its distribution to the states of Aguascalientes, Puebla, Hidalgo and Oaxaca (Flannery, 1967, Mooser, 1972, Tovar and Montellano, 2006, Tovar et al., 2007, Castillo-Cerón et al., 2009). Gopherus donlaloi (Reynoso and Montellano-Ballesteros, 2004), is a valid species different from the giant Gopherus turtles of North America. It is the youngest record of the giant turtle lineage with the southernmost distribution. Its discovery explains that changes in carapace morphology in ontogeny are more related to changes on size rather than to sexual dimorphism (Reynoso and Montellano-Ballesteros, 2004).

Currently, Kinosternon (Kinosternidae) includes around twenty species extending from Central and southeast of USA to northern Brazil and Argentina (Bonin et al., 2006; Rhodin et al., 2017). Fossils are known in Mexico and Central America from the Late Miocene to the Late Pleistocene, extending geographically from northern Mexico to El Salvador. Fossils of several Kinosternon species have been reported outside their current distribution area. This includes Kinosternon scorpioides reported from Zacatecas, Aguascalientes, Morelos and Chiapas (Mooser, 1980, Guzmán and Polaco, 1998; Arroyo-Cabrales et al., 2004; Luna-Espinosa and Carbot-Chanona, 2009), K. flavescens from Sonora (Van Devender et al., 1985), and K. hirtipes from Oaxaca (Cruz et al., 2009). We believe this material needs to be updated since geographical evidence may indicate that they are not well determined, or that their distribution in the past was much more extensive than today.

Trachemys (Emydidae), currently extends from southeast of USA to Brazil (Bonin et al., 2006; Fritz et al., 2012). Reports of Trachemys sp. from Zacatecas and Puebla (Guzmán and Polaco, 2000; HerreraFlores, 2009) also need to be revised since nowadays, the distribution of Trachemys does not encompass states on the high plateau of Mexico (Legler and Vogt, 2013). Fossils of this genus have been reported from the late Miocene to the Late Pleistocene in Mexico and Central America. Its restricted distribution during the Neogene and Quaternary could be caused by droughts derived from the gradual cooling in the global climate.

\section{CONCLUSION}

The fossil record of turtles in Mexico, Central America and the Caribbean Islands is scarce but important, because they document the history of a large area that has served as a transition between the rest of North America and South America. It ranges from the Late Jurassic to the late Pleistocene. However, as expected, there are still hiatuses in the chronological record since the reports of the Paleocene are null and very scarce for the Eocene and Oligocene, mainly because few outcrops are known to date. The periods with the greatest fossil record of Testudines are the Campanian and Pleistocene, being this last epoch where more species have been recorded. Among all fossil turtle reports, Kinosternon and Gopherus are the best represented taxa. Guatemala and Belize, in Central America, do not have reports of fossil turtles, perhaps, because few paleontological works have been done in those countries.

Finally, there is a lack of specialists for the study of fossil Testudines in Mexico, Central America and the Caribbean Islands, compared to the large number of specimens in museum collections that has not been studied.

\section{ACKNOWLEDGEMENT}

This paper fulfills a partial requirement for the Doctoral Thesis of the Programa de Posgrado en Biodiversidad y Conservación de Ecosistemas Tropicales, Universidad de Ciencias y Artes de Chiapas of Gerardo Carbot-Chanona. We thank Marisol Montellano-Ballesteros, José Rubén Guzmán-Gutiérrez and the Wikipaleo group for sharing bibliography. Rubén Rodríguez-de la Rosa (Universidad Autónoma de Zacatecas), Alberto Blanco-Piñón (independient researcher), Alejandra González Verdín (Instituto Nacional de Antropología e Historia, Aguascalientes), Jesús Alvarado-Ortega (Universidad Nacional Autónoma de México), Oliver Ariel López-Conde (Universidad Nacional Autónoma de México), Héctor Porras Múzquiz (Museo de Paleontología de Múzquiz), Edwin Cadena (Universidad del Rosario, Colombia), Cesar A. Laurito and Ana Lucia Valerio (Museo Nacional de Costa Rica) shared unpublished information and photographs. We thank reviewers Edwin Cadena and Evangelos Vlachos for the comments that improved this manuscript. Gaby Goeckner provided proofreading assistance.

\section{REFERENCES}

Acuña-Mesén, R.A., Laurito-Mora, C.A., 1996, Nueva especie de Rhinoclemmys Fitzinger, 1836 (Chelonii, Cryptodira) del Cenozoico tardío de Costa Rica: Ameghiniana, 33(3), 271-278.

Aguilar Cabrera, B.R., Guzmán Gutiérrez, J.R., Palafox Solís, P., Rodríguez Huerta, M., 2013, Nuevo registro de tortugas fósiles del Neógeno de Jalisco, México (abstract), in Reynoso, V.H., Oseguera-Montiel, B., Flores-Mejía, P. (eds), Programa y Resúmenes del VIII Congreso Latinoamericano de Paleontología and XIII Congreso Mexicano de Paleontología, Guanajuato, Guanajuato: Mexico, Sociedad Mexicana de Paleontología, A.C. - Museo Dugès, Universidad de Guanajuato, p. 32.

Aguilera, J., 1869, Bosquejo geológico de México: Boletín del Instituto Geológico de México, 4-6, 270 pp.

Albury, N.A., Franz, R., Rimoli, R., Lehman, P., Rosenberger, A.L., 2018, Fossil land tortoises (Testudines: Testudinidae) from the Dominican Republic, West Indies, with a description of a new species: American Museum Novitates, 3904, 1-28.

Álvarez, T., Huerta, P., 1975, Restos óseos de anfibios y reptiles en Tlapacoya IV México: Boletín del Instituto Nacional de Antropología e Historia, época II, 11, 37-42.

Aranda Manteca, F.J., 2013, Los vertebrados fósiles en el norte de la península de Baja California: Paleontología Mexicana, 3(1), 84-91.

Arroyo-Cabrales, J., Corona-M., E., Polaco, O.J., Cruz Silva, J.A., Córdova, M., Canto, G., Basante, O., 2004, Recent excavations in the Cueva Encantada, Chimalacatlán, Morelos, México: Current Research in the Pleistocene, 21, 9-11.

Auffenberg, W., 1967, Notes on West Indian tortoises: Herpetologica, 23(1), 34-44.

Auffenberg, W., 1971, A new fossil tortoise, with remarks on the origin of South 
American Testudines: Copeia, 1, 106-117.

Barrios Rivera, H., 1985, Estudio analítico del registro paleovertebradológico de México: Mexico DF., Mexico, Facultad de Ciencias, Universidad Nacional Autónoma de México, bachelor thesis, $474 \mathrm{pp}$.

Blanco, A., Stinnesbeck, W., López-Oliva, J.G., Frey, E., Adatte, T., González, A.H., 2001, Vallecillo, Nuevo León: una nueva localidad fosilífera del Cretácico Tardío en el noreste de México: Revista Mexicana de Ciencias Geológicas, 18(2), 186-199.

Bonin, F., Devaux, B., Dupré, A., 2006, Turtles of the World: Baltimore, Maryland, The Johns Hopkins University Press, 416 pp.

Bramble, D.M., 1982, Scaptochelys: Generic revision and evolution of gopher tortoises: Copeia, 1982(4), 852-867.

Brattstrom, H.B., 1955, Records of some Pliocene and Pleistocene reptiles and amphibians from Mexico: Bulletin, Southern California Academy of Science, 54, 1-4.

Brattstrom, B.H., 1961, Some new fossil tortoises from western North America with remarks on zoogeography and paleontology tortoises: Journal of Paleontology, 35(3), 543-560.

Bravo-Cuevas, V.M., 2001, Pleistocene faunal asemblage from southcentral region of Hidalgo, central Mexico: Journal of Vertebrate Paleontology, 21(3), 35A.

Brinkman, D.B., 2014, Turtles of the Mesozoic of Mexico, in Rivera-Sylva, H.E., Carpenter, K., Frey, E. (eds.), Dinosaurs and the other reptiles from the Mesozoic of Mexico: Bloomington, Indiana University Press, 30-43.

Brinkman, D.B., Rodríguez-de la Rosa, R.A., 2006, Nonmarine turtles from the Cerro del Pueblo Formation (Campanian), Coahuila state, Mexico, in Lucas, S.G., Sullivan, R.M. (eds.), Late Cretaceous vertebrates from the Western Interior: New Mexico Museum of Natural History and Science Bulletin, 35, 229-233.

Brinkman, D.B., Aquillon-Martinez, M.C., De Leon Dávila, C.A., Jamniczky, H., Eberth, D.A., Colbert, M., 2009, Euclastes coahuilaensis sp. nov., a basal cheloniid turtle from the late Campanian Cerro del Pueblo Formation of Coahuila State, Mexico: PaleoBios 28(3), 76-88.

Brinkman, D., Aguillon-Martinez, M.C., Hutchison, J.H., Brown, C.M., 2016, Yelmochelys rosarioae gen. et sp. nov., a stem kinosternid (Testudines; Kinosternidae) from the Late Cretaceous of Coahuila, Mexico: PaleoBios, $33,1-20$.

Broin, F. de, 1980, Les Tortues de Gadoufaoua (Aptien du Niger); aperc, usur la paléobiogéographie des Pelomedusidae (Pleurodira): Mémoires de la Société géologique de France, 139, 39-46.

Broin, F. de, 1984, Proganochelys ruchae n. sp., chélonien du Trias supérieur de Thailande: Stvdia Palaeocheloniologica, 1, 87-97.

Buitrón Sánchez, B.E., Almazán Vázquez, E., Gómez Espinosa, M.C., 2010, Paleontología General Invertebrados: Mexico, Universidad Nacional Autónoma de México, Facultad de Ingeniería, 317 pp.

Cadena, E., Joyce, W.G., 2015, A review of the fossil record of turtles of the Clades Platychelyidae and Dortokidae: Bulletin of the Peabody Museum of Natural History, 56(1), 3-20, DOI: http://dx.doi.org/10.3374/014.056.0101.

Cadena, E., Bourque, J.R., Rincon, A.F., Bloch, J.I., Jaramillo, C.A., Macfadden, B.J., 2012, New turtles (Chelonia) from the Late Eocene through Late Miocene of the Panama Canal Basin: Journal of Paleontology, 86(3), 539-557.

Cadena Rueda, E.A., Gaffney, E.S., 2005, Notoemys zapatocaensis, a new sidenecked turtle (Pleurodira: Platychelyidae) from the Early Cretaceous of Colombia: AmericanMuseum Novitates, 3470, 1-19.

Carbot-Chanona, G., 2011, Estudio preliminar de restos de vertebrados miocénico-tardíos en Chiapas, México (abstract), in XII Congreso Nacional de Paleontología: Puebla, Puebla, Benemérita Universidad Autónoma de Puebla, p. 40.

Carbot-Chanona, G., Ovalles-Damián, E., 2013, Registro de vertebrados fósiles, in La Biodiversidad en Chiapas: Estudio de estado: Comisión Nacional para el Conocimiento y Uso de la Biodiversidad y Gobierno del Estado de Chiapas, Vol. II, 261-274.

Carbot-Chanona, G., Rivera-Velázquez, G., Jiménez-Hidalgo, E., Reynoso, V.H., 2020, The first Pan-Carettochelys turtle in the Neogene of the American continent and its paleobiogeographical relevance: Journal of South American Earth Sciences, 104, 102925, DOI: https://doi.org/10.1016/j. jsames.2020.102925.

Carranza-Castañeda, O., 2006, Late Tertiary fossil localities in central Mexico, between $19^{\circ}-23^{\circ} \mathrm{N}$, in Carranza-Castañeda, O., Lindsay, E.H. (eds.), Advances in late Tertiary vertebrate paleontology in Mexico and the Great American Biotic Interchange: Universidad Nacional Autónoma de México, Instituto de Geología and Centro de Geociencias, Publicación Especial 4, 45-60.

Castillo Cerón, J.M., Cabral Perdomo, M.A., Carranza-Castañeda, O., 1996, Vertebrados fósiles del Estado de Hidalgo: Pachuca, Hidalgo, Universidad Autónoma del Estado de Hidalgo, 127 pp.

Castillo-Cerón, J.M., Nájera-Hernández, L., Medina-Romero, M., Goyenechea, I., Palma-Ramírez, A., 2009, Consideraciones sobre la distribución de las especies de testudínidos del Pleistoceno de América del Norte (abstract), in XI Congreso Nacional de Paleontología: Juriquilla, Querétaro, Universidad Nacional Autónoma de México, p. 13.

Chacón-Soria, E., Aguilar, F.J., 2010, El Abrevadero, Chihuahua: a site with remains of Pleistocene fauna and artifacts of early peoples in northwestern Mexico: Current Research in the Pleistocene, 27, 8-9.

Chávez Galván, B., Guzmán, A.F., Polaco, O.J., 2013, Sinopsis de la herpetofauna en contextos paleontológicos y arqueológicos del Cuaternario de México: Instituto Nacional de Antropología e Historia, Colección Interdisciplina, Serie Sumaria, $306 \mathrm{pp}$.

Cisneros, J.C., 2005, New Pleistocene vertebrate fauna from El Salvador: Revista Brasileira de Paleontologia, 8(3), 239-255.

Coto Rojas, A., Acuña Mesén, R.A., 1986, Filogenia de Geochelone costarricensis y la familia Testudinidae (Reptilia: Testudines) en el continente americano: Revista de Biología Tropical, 34(2), 199-208.

Crawford, N.G., Faircloth, B.C., McCormack, J.E., Brumfield, R.T., Winker, K., Glenn, T.C., 2012, More than 1000 ultraconserved elements provide evidence that turtles are the sister group of archosaurs: Biology Letters, 8, 783-786, doi:10.1098/rsbl.2012.0331.

Cruz, J.A., Arroyo-Cabrales, J., Viñas-Vallverdú, R., 2009, Tortugas fósiles del Pleistoceno tardío de Santiago Chazumba, Oaxaca: Boletín de la Sociedad Geológica Mexicana, 61(2), 225-232.

Cruz, J.A., Arroyo-Cabrales, J., Reynoso, V.H., 2016, Reconstructing the paleoenvironment of Loltún Cave, Yucatán, Mexico, with Pleistocene amphibians and reptiles and their paleobiogeographic implications: Revista Mexicana de Ciencias Geológicas, 33(3), 342-354.

Delgadillo-Escobar, A., Rodríguez-de la Rosa, R.A., 2011, Reporte preliminar sobre una tortuga marina (Protostegidae) del Turoniano del Norte de México (abstract), in XII Congreso Nacional de Paleontología: Puebla, Puebla, Benemérita Universidad Autónoma de México, p. 50.

De la Fuente, M.S., Iturralde-Vinent, M., 2001, A new pleurodiran turtle from the Jagua Formation (Oxfordian) of western Cuba: Journal of Paleontology, 75(4), 860-869.

Edwards, T., Karl, A.E., Vaughn, M., Rosen, P.C., Meléndez Torres, C., Murphy, R.W., 2016, The desert tortoise trichotomy: Mexico hosts a third, new sister-species of tortoise in the Gopherus morafkai-G. agassizii group: ZooKeys, 562, 131-158, doi: 10.3897/zookeys.562.6124.

Ernst, C.H., Barbour, R.W., 1989, Turtles of the World: Washington D.C. and London, Smithsonian Institution Press, $313 \mathrm{pp}$.

Ferrusquía-Villafranca, I., Torres-Roldán, V., 1980, El registro de mamíferos terrestres del Mesozoico y Cenozoico de Baja California: Revista del Instituto de Geología de la Universidad Nacional Autónoma de México, $4(1), 56-62$.

Ferrusquía-Villafranca, I., Ruiz-González, J.E., Martínez-Hernández, E., TorresHernández, J.R., Woolrich-Piña, G., 2014, New Miocene local fauna from the Sierra Madre Oriental at San Luis Potosí, Central-East Mexico, and its paleontologic significance: Geobios, 47, 199-220, doi:10.1016/j. geobios.2014.06.004.

Field, D.J., Gauthier, J.A., King, B.L., Pisani, D., Tyler R. Lyson, T.R., Kevin J. Peterson, K.J., 2014, Toward consilience in reptile phylogeny: miRNAs support an archosaur, not lepidosaur, affinity for turtles: Evolution \& Development, 16(4), 189-196, doi: 10.1111/ede.12081.

Flannery, K.V., 1967. Vertebrate fauna and hunting patterns, in Byers, D.S. (ed.), The prehistory of the Tehuacan Valley: Austin, University of Texas Press, 132-177.

Flannery, K.V., Wheeler, J.C., 1986, Animal food remains from preceramic Guilá Naquitz, in Flannery K.W. (ed.), Guilá Naquitz, archaic foraging and early agriculture in Oaxaca, Mexico: Academic Press Inc., 285-295.

Flores-Villela, O., 1993. Herpetofauna of Mexico: distribution and endemism, 
in Ramamoorthy, T.P., Bye, R., Lot, A., Fa, J. (eds.), Biological diversity of Mexico: origins and distribution: New York, Oxford University Press, 253-280.

Franz, R., Franz, S.E., 2009, New fossil land tortoise in the genus Chelonoidis (Testudines: Testudinidae) from the northern Bahamas, with an osteological assessment of other neotropical tortoises: Bulletin Florida Museum Natural History, 49(1), 1-44.

Franz, R., Woods, C.A., 1983, A fossil tortoise from Hispaniola: Journal of Herpetology, 1(17), 79-81.

Fritz, U., Stuckas, H., Vargas-Ramírez, M., Hundsdörfer, A.K., Maran, J., Päckert, M., 2012, Molecular phylogeny of Central and South American slider turtles: implications for biogeography and systematics (Testudines: Emydidae: Trachemys): Journal of Zoological Systematics and Evolutionary Research, 50(2), 125-136.

Gaffney, E.S., 1990, The comparative osteology of the Triassic turtle Proganochelys: Bulletin of the American Museum of Natural History, 194, 1-263.

Gaffney, E.S., Kitching, J.W., 1994, The most ancient African turtle: Nature, 369, 55-58.

Gaffney, E.S., Kitching, J.W., 1995, The morphology and relationships of Australochelys, an Early Jurassic turtle from South Africa: American Museum Novitates, 3130, 1-29.

Gaffney, E.S., Tong, H., Meylan, P.A., 2006, Evolution of the side-necked turtles: The families Bothremydidae, Euraxemydidae, and Araripemydidae: Bulletin of the American Museum of Natural History, 300, 1-700.

García, R., Reynoso-Rosales, V.H., 2002, Dos caparazones de tortugas del género Bothremys de la Formación Cerro del Pueblo y su importancia en la biogeografía de la familia Bothremydidae (abstract), in VIII Congreso Nacional de Paleontología: Guadalajara, Jalisco, Mexico, Sociedad Mexicana de Paleontología, p. 51.

García, R., Reynoso-Rosales, V.H., 2006, Nuevo género de tortugas pleuródiras de la Formación Tlayúa, Puebla y su importancia en la biogeografía de los pelomedusoides (abstract), in X Congreso Nacional de Paleontología y libreto guía excursión a Tepexi de Rodríguez: Puebla, Mexico D.F., Mexico, Universidad Nacional Autónoma de México, Publicación Especial 5, p. 39.

González Barba, G., Alvarado Ortega, J., 2009, Los peces Cupleiformes del Oligoceno Tardío (Chattiano) en las Formaciones El Cien y San Gregorio de Baja California Sur, México (abstract), in XI Congreso Nacional de Paleontología, Juriquilla, Querétaro: Universidad Nacional Autónoma de México, p. 28.

González-Barba, G., Herrera-Gil, L.A., Rosales-López, A., 1998, Catálogo de las localidades fosilíferas de la cuenca Buenavista-San José del Cabo, Baja California Sur, México (Parte I: Trópico de Cáncer-San José del Cabo) (abstract), in VI Congreso Nacional de Paleontología, México: Mexico D.F., Sociedad Mexicana de Paleontología, p. 25.

González-Romo, O.F., Rodríguez-de la Rosa, R.A., Navarro-Velasco, J.L., 2012, Huellas de tortugas del Cretácico del norte de Zacatecas, México: un reporte preliminar (abstract), in VI Jornadas Paleontológicas y I Simposio de Paleontología en el Sureste de México: 100 años de Paleontología en Chiapas, Tuxtla Gutiérrez, Chiapas: Chiapas, Mexico, Secretaría de Medio Ambiente e Historia Natural, p. 22.

Güenther, E.W., 1968, Untersuchungen zur jungeiszeitlichen und nacheiszeitlichen geologischen und paläontologischen geschichte, in Franz, T. (Ed.), Investigaciones sobre la historia geológica y paleontológica del Pleistoceno superior y del Postpleistoceno: Wiesbaden, El Proyecto México de la Fundación Alemana para la Investigación Científica (tomo 1), p. 32-37.

Guerrero-Arenas, R., Jiménez-Hidalgo, E., Genise, J.F., 2020, Burrow systems evidence nonsolitary geomyid rodents from the Paleogene of southern Mexico: PLoS ONE 15(3), e0230040. Doi: https://doi.org/10.1371/journal. pone.0230040

Guillon, J.-M., Guéry, L., Hulin, V., Girondot, M., 2012, A large phylogeny of turtles (Testudines) using molecular data: Contributions to Zoology, 81(3), 147-158.

Guzmán, A.F., Polaco, O.J., 1998, Tortugas fósiles de Durango y Zacatecas (abstract), in VI Congreso Nacional de Paleontología, México: Mexico D.F., Sociedad Mexicana de Paleontología, 28-29.

Guzmán, A.F., Polaco, O.J., 2000, Vertebrados pleistocénicos de Los Tanques, Zacatecas (abstract), in VII Congreso Nacional de Paleontología y I
Simposio Geológico en el Noroeste de México: Linares, Nuevo León, Universidad Autónoma del Estado de Nuevo León, 100-101.

Hernández Junquera, A., 1977, Fauna local Laguna de la Media Luna, Pleistoceno tardío, municipio de Río Verde, San Luis Potosí, México: Mexico, D.F. Facultad de Ciencias, Universidad Nacional Autónoma de México, bachelor thesis, $102 \mathrm{pp}$.

Herrera-Flores, J.A., 2009, Restos fósiles de tortugas en San Buenaventura Nealtican, Puebla: Acta Zoológica Mexicana, 25(3), 455-464.

Hibbard, C.W., 1955, Pleistocene vertebrates from the Upper Becerra (Becerra Superior) Formation, Valley of Tequixquiac, Mexico, with notes on other Pleistocene forms: Contributions from the Museum of Paleontology, University of Michigan, 12(5), 47-96.

Hulbert, R.C., Pratt, A.E., 1998, New pleistocene (Rancholabrean) vertebrate faunas from coastal Georgia: Journal of Vertebrate Paleontology, 18, 412 429, doi: http://dx.doi.org/10.1080/02724634.1998.10011069.

Jiménez-Hidalgo, E., Smith, K.T., Guerrero-Arenas, R., Alvarado-Ortega, J., 2015, The first Late Eocene continental faunal assemblage from tropical North America: Journal of South American Earth Sciences, 57, 39-48.

Joyce, W.G., 2017, A review of the fossil record of basal Mesozoic turtles: Bulletin of the Peabody Museum of Natural History, 58(1), 65-113, doi: http:// dx.doi.org/10.3374/014.058.0105.

Joyce, W.G., Parham, J.F., Gauthier, J.A, 2004, Developing a protocol for the conversion of rank-based taxon names to phylogenetically defined clade names, as exemplified by turtles: Journal of Paleontology, 78, 989-1013.

Julien, A.J., 1878, Gigantic land tortoises: Nature, 19,30-31.

Laurito M., C., Valerio Z., A.L., Gómez P., L.D., Mead, J.I., Pérez G., E.A., Pérez R., L.G., 2005, A Trionychidae (Reptilia: Testudines, Cryptodira) from the Pliocene of Costa Rica, southern Central America: Revista Geológica de América Central, 32, 7-11.

Lapparent de Broin, F., de la Fuente, M.S., Fernández, M.S., 2007, Notoemys laticentralis (Chelonii, Pleurodira), Late Jurassic of Argentina: new examination of the anatomical structures and comparisons: Revue de Paléobiologie, Genève, 26(1), 99-136.

Legler, J.M., Vogt, R.C., 2013, The turtles of Mexico: land and freswater forms Berkeley and Los Angeles, University of California Press, $402 \mathrm{pp}$.

Leidy, J., 1868, Notice of some vertebrate remains from the West Indian islands: Proceedings of the Academy of Natural Sciences of Philadelphia, 20, 178-180.

Li, C., Wu, X.-C., Rieppel, O., Wang, L.-T., Zhao, L.-J., 2008, An ancestral turtle from the Late Triassic of southwestern China: Nature, 456, 497-501, doi:10.1038/nature07533.

Liu, Z., Pagani, M., Zinniker, D., DeConto, R., Huber, M., Brinkhuis, H., Shah, S.R., Leckie, R.M., Pearson, A., 2009, Global cooling during the EoceneOligocene climate transition: Science, 323(5918), 1187-1190, DOI: $10.1126 /$ science. 1166368

Lichtig, A.J., Lucas, S.G., Alvarado, G.E., 2018, Reappraisal of the holotype of "Testudo" costarricensis, a tortoise supposedly from the Oligocene or Lower Miocene of Costa Rica: Revista Geológica de América Central, 59, 41-49, doi: 10.15517/rgac.v59i0.34156.

López R., M.C., Guzmán García, M.G., Hernández Nava, M., Castillo Cerón, J., 2002, Tortugas pleistocénicas del estado de Hidalgo, México (abstract), in VIII Congreso Nacional de Paleontología: Guadalajara, Jalisco, Mexico, Sociedad Mexicana de Paleontología, p. 115.

López-Conde, O.A., Sterli, J., Alvarado-Ortega, J., Chavarría-Arellano, M.L. 2016, A new platychelyid turtle (Pan-Pleurodira) from the late Jurassic (Kimmeridgian) of Oaxaca, Mexico: Papers in Palaeontology, 2016, 161174, https://doi.org/10.1002/spp2.1069.

López-Conde, O.A., Sterli, J., Chavarría-Arellano, M.L., Brinkman, D.B., Montellano-Ballesteros, M., 2018, Turtles from the Late Cretaceous (Campanian) of El Gallo Formation, Baja California, Mexico: Journal of South American Earth Sciences, 88, 693-699, DOI: https://doi. org/10.1016/j.jsames.2018.10.005.

López-Conde, O.A., Sterli, J., Alvarado-Ortega, J., Chavarría-Arellano, M.L., Porras-Múzquiz, 2019, The first record of Desmatochelys cf. D. lowii from the Late Cretaceous (Campanian) of Coahuila, Mexico: Journal of South American Earth Sciences, 94, https://doi.org/10.1016/j.jsames.2019.05.020

Lorenzo, J.L., Mirambell, L., 1986, Preliminary report on archaeological and paleoenvironmental studies in the area of El Cedral, San Luis Potosi, Mexico 1977-1980, in Bryan, A.L. (ed.), New evidence for the Pleistocene 
peopling of the Americas, Center for the Study of Early Man: Orono, University of Maine, 107-113.

Lucas, S.G., Kues, B.S., González-León, C.M., 1995, Paleontology of the Upper Cretaceous Cabullona Group, northeastern Sonora, in Jacques-Ayala, C., González-León, C.M., Roldán-Quintana, J. (eds.), Studies on the Mesozoic of Sonora and Adjacent Areas: Boulder, Colorado, Geological Society of America Special Paper 301, 143-165.

Lucas, S.G., García, R., Espinoza, E., Alvarado, G.E., Hurtado de Mendoza, L., Vega, E., 2008, The fossil mammals of Nicaragua: New Mexico Museum of Natural History and Science Bulletin, 44, 417-430.

Luna-Espinosa, J.R., Carbot-Chanona, G., 2009, First record of Late-Pleistocene turtles from Chiapas, Mexico: Current Research in the Pleistocene, 26, 162-164.

MacPhee, R.D.E., Iturralde-Vinent, M.A., Gaffney, E.S., 2003, Domo de Zaza, an early Miocene vertebrate locality in south-central Cuba, with notes on the tectonic evolution of Puerto Rico and the Mona Passage: American Museum Novitates, 3394, 1-42.

McDonald, H.G., Carranza-Castañeda, O., 2017, Increased xenarthran diversity of the Great American Biotic Interchange: a new genus and species of ground sloth (Mammalia, Xenarthra, Megalonychidae) from the Hemphillian (late Miocene) of Jalisco, Mexico: Journal of Paleontology, 1-14, doi: 10.1017/jpa.2017.45.

Messing, H.J., 1986, A late Pleistocene-Holocene fauna from Chihuahua, Mexico: The Southwestern Naturalist, 31(3), 277-288.

Meylan, P.A., 1987, The phylogenetic relationships of soft-shelled turtles (Family Trionychidae): American Museum of Natural History, 186(1), 1-101.

Meylan, P.A., 1995, Pleistocene amphibians and reptiles from the Leisey Shell Pit, Hillsborough Conty, Florida: Bulletin Florida Museum Natural History, 37(9), 273-297.

Meylan, P.A., 1996, Skeletal morphology and relationships of the early Cretaceous side-necked turtle, Araripemys barretoi (Testudines: Pelomedusoides: Araripemydidae), from the Santana Formation of Brazil: Journal of Vertebrate Paleontology, 16, 20-33, doi: 10.1080/02724634.1996.10011280.

Meylan, A.B., Meylan, P.A., 2000, Introducción a la evolución, historias de vida y biología de las tortugas marinas, in Eckert, K.L., Bjorndal, K.A., AbreuGrobois, F.A., Donnelly, M. (eds.), Técnicas de investigación y manejo para la conservación de las tortugas marinas: Washington, DC, SSC/IUCN Marine Turtle Specialist Group, Publicación No. 4, 1-3.

Miller, W., 1980, The late Pliocene Las Tunas local fauna from southernmost Baja California, Mexico: Journal of Paleontology, 54(4), 762-805.

Moodie, K.B., Van Devender, T.R., 1979, Extinction and extirpation in the herpetofauna of the southern High Plains with emphasis on Geochelone wilsoni (Testudinidae): Herpetologica, 35(3), 198-206.

Mooser, O., 1958, La fauna Cedazo del Pleistoceno de Aguascalientes: Anales del Instituto de Biología, 29(1-2), 409-452.

Mooser, O., 1972, A new species of Pleistocene fossil tortoise, genus Gopherus, from Aguascalientes, Aguascalientes, Mexico: The Southwestern Naturalist, 17(1), 61-65.

Mooser, O., 1980, Pleistocene fossil turtles from Aguascalientes, state of Aguascalientes: Revista de la Universidad Nacional Autónoma de México, 4(1), 63-66.

Moreno-Flores, J.O., García-Zepeda, M.L., Díaz-Sibaja, R., Eng-Ponce, J., Arroyo-Cabrales, J., 2017, Estudio preliminar de los reptiles del Pleistoceno Tardío de La Cinta-Portalitos, Michoacán-Guanajuato, México (abstract) in XV Congreso Nacional de Paleontología: San Luis Potosí, Mexico, Paleontología Mexicana, publicación especial 2, p. 103.

Morgan, G.S., 1993, Quaternary land vertebrates of Jamaica, in Wright, R.M., Robinson, E. (eds.), Biostratigraphy of Jamaica: Boulder, Colorado, Geological Society of America Memoirs, 12, 417-442, doi: https://doi. org/10.1130/MEM182-p417.

Moscato, D.A., Jasinski, S.E., 2016, First record of fossil chelydrid and trionychid turtles from the Pleistocene of Sonora, in Sullivan, R.M., Lucas, S.G. (eds.), Fossil Record 5: New Mexico Museum of Natural History and Science Bulletin, 74, 163-168.

Mullerried, F.K.G., 1943, Fósiles raros de México III.- Una tortuga fósil del Estado de Chiapas: Anales del Instituto de Biología, 13(2), 623-624.

Murphy, R.W., Berry, K.H., Edwards, T., Leviton, A.E., Lathrop, A., Riedle, J.D., 2011, The dazed and confused identity of Agassiz's land tortoise, Gopherus agassizii (Testudines, Testudinidae) with the description of a new species, and its consequences for conservation: ZooKeys, 113, 39-71, doi: 10.3897/ zookeys.113.1353.

Nájera Hernández, L., 2006, Patrones de distribución de la familia Testudinidae del Pleistoceno-Holoceno de América del Norte y descripción taxonómica de algunos fósiles del Estado de Hidalgo, México: Pachuca, Hidalgo, Mexico, Instituto de Ciencias Básicas e Ingeniería, Universidad Autónoma del Estado de Hidalgo, bachelor tesis, 103 pp.

Nájera Hernández, L., Castillo Cerón, J.M., 2004, Fósiles de testudínidos del Estado de Hidalgo (abstract), in IX Congreso Nacional de Paleontología, Tuxtla Gutiérrez, Chiapas: Chiapas, Mexico, Instituto de Historia Natural y Ecología, p. 81.

Parham, J.F., Pyenson, N.D., 2010, New sea turtle from the Miocene of Peru and the iterative evolution of feeding ecomorphologies since the Cretaceous: Journal of Vertebrate Paleontology, 84(2), 231-247, doi: http://dx.doi. org/10.1666/09-077R.1.

Peña-Serrano, J., Miranda-Flores, M., 2006, Hallazgo de un perezoso gigante y fauna asociada del Pleistoceno tardío en el municipio de Atoyac, Veracruz, México (abstract), in X Congreso Nacional de Paleontología y libreto guía excursión a Tepexi de Rodríguez, Puebla: Mexico D.F., Universidad Nacional Autónoma de México, Publicación Especial 5, p. 64.

Pérez-García, A., 2019, Identification of the Lower Cretaceous pleurodiran turtle Taquetochelys decorata as the only African araripemydid species: Comptes Rendus Palevol, 18(1), 24-32, https://doi.org/10.1016/j.crpv.2018.04.004.

Polaco-Ramos, O.J., 1981, Restos fósiles de Glossotherium y Eremotherium (Edentata) en México: Porto Alegre, Brasil, Anais II Congresso LatinoAmericano du Paleontología, 2, 819-833.

Powell, R.L., Newman, B.C., Lukefahr, W.D., Thomas, R.G., 2016, Morphometric analysis of carapacial bones: discriminating between two genera of South Texas (North America) Pleistocene tortoises (Testudinidae): Historical Biology, 28(8), 1041-1049, doi: 10.1080/08912963.2015.1088535.

Price, L.I., 1973, Quelônio amphichelydia no Cretáceo inferior do nordestedo Brazil: Revista Brasileira de Geociências, 3, 84-96.

Reynoso, V.H., 2006, Research on fossil amphibians and reptiles in Mexico, from 1869 to early 2004 (including marine forms but excluding pterosaurs, dinosaurs, and obviously, birds), in Vega, F.J., Nyborg, T.G., Perrilliat, M.C., Montellano-Ballesteros, M., Cevallos-Ferriz, S.R.S., Quiroz-Barroso, S.A. (eds.), Studies on Mexican Paleontology: The Netherlands, Springer, 209-231.

Reynoso, V.H., Montellano-Ballesteros, M., 2004, A new giant turtle of the genus Gopherus (Chelonia: Testudinidae) from the Pleistocene of Tamaulipas, Mexico, and a review of the phylogeny and biogeography of gopher tortoises: Journal of Vertebrate Paleontology, 24(4), 822-837.

Reynoso, V.H., Cabral Perdomo, M.A., Clark, J., 2000, The reptiles of the Tlayúa Formation, Guidebook Field Trip, in 60th Annual Meeting of the Society Vertebrate Paleontology: Mexico D.F., Universidad Nacional Autónoma de México, Avances en Investigación, Publicación Especial, 106-111.

Rhodin, A.G.J., Iverson, J.B., Bour, R., Fritz, U., Georges, A., Shaffer, H.B., van Dijk, P.P., 2017, Turtles of the World: Annotated checklist and atlas of taxonomy, synonymy, distribution, and conservation status (8th Ed.), in Rhodin, A.G.J., Iverson, J.B., van Dijk, P.P., Saumure, R.A., Buhlmann, K.A., Pritchard, P.C.H., Mittermeier, R.A. (eds.), Conservation Biology of Freshwater Turtles and Tortoises: A Compilation Project of the IUCN/SSC Tortoise and Freshwater Turtle Specialist Group: Lunenburg, MA, New York, NY, USA, Chelonian Research Monographs 7, 292 pp., doi: 10.3854/ crm.7.checklist.atlas.v8.2017.

Rieppel, O., deBraga, M., 1996, Turtle as diapsid reptiles: Nature, 384, 453-455.

Rivera-Sylva, H.E., González- González, A.H., Padilla Gutiérrez, J.M., De la Peña Oviedo, I., Oyervidez Salazar, A.I., 2011, Nueva localidad de la Formación Cerro del Pueblo (Cretácico Tardío: Campaniano) en Coahuila, México (abstract), in XII Congreso Nacional de Paleontología: Puebla, Puebla, Mexico, Benemérita Universidad Autónoma de Puebla, p. 118.

Rodríguez-de la Rosa, R.A., 2003, Pterosaur tracks from the latest Campanian Cerro del Pueblo Formation of southeastern Coahuila, Mexico, in Buffetaut, E., Mazin, J.-M. (eds.), Evolution and Palaeobiology of Pterosaurs: London, Geological Society, Special Publications, 217, 275-282.

Rodríguez-de la Rosa, R.A., Aranda-Manteca, F.., 2000, Nuevos hallazgos de vertebrados de la Formación El Gallo (Campaniano tardío) del estado de Baja California (abstract), in VII Congreso Nacional de Paleontología y I Simposio Geológico en el Noroeste de México: Linares, Nuevo León: 
Mexico, Universidad Autónoma del Estado de Nuevo León, p. 65.

Rodríguez-de la Rosa, R.A., Cevallos-Ferriz, S.R.S., 1998, Vertebrates of the El Pelillal locality (Campanian, Cerro del Pueblo Formation), southeastern Coahuila, Mexico: Journal of Vertebrate Paleontology, 18(4), 751-764.

Rodríguez-de la Rosa, R.A., Dávila-Rodríguez, J.R., 1998, Una icnita de quelonio del Cretácico superior de Coahuila, México (abstract), in VI Congreso Nacional de Paleontología: Mexico D.F., Mexico, Universidad Nacional Autónoma de México, 62-63.

Rodríguez-de la Rosa, R.A., Porras Múzquiz, H.G., Blanco-Piñón, A., 2011, Desmatochelys lowi (Chelonioidea, Protostegidae) en el Turoniano del Norte de México (abstract), in XII Congreso Nacional de Paleontología: Puebla, Puebla, Mexico, Benemérita Universidad Autónoma de Puebla, p. 120.

Rodríguez-de la Rosa, R.A., Fernández-Barajas, M.R., Valdes-Vergara, N.A., Prado-Escamilla, E., Mireles-Hernández, B.A., Trejo-Alonso, M., Martínez-Hernández, E., 2017, Huellas fósiles de vertebrados del Cretácico Inferior de Santa Ana Teloxtoc, Puebla, México (abstract), in XV Congreso Nacional de Paleontología: San Luis Potosí, Mexico, Paleontología Mexicana, publicación especial 2, p. 137.

Segura, A.P., 1944, Estudio de la primera especie nueva de tortuga fósil de Costa Rica, con algunas generalidades sobre el orden Testudines: La Escuela de Farmacia, 77-78, 13-24.

Shaffer, H.B., McCartney-Melstad, E., Near, T.J., Mount, G.G., Spinks, P.Q., 2017, Phylogenomic analyses of 539 highly informative loci dates a fully resolved time tree for the major clades of living turtles (Testudines): Molecular Phylogenetics and Evolution, 115, 7-15.

Szczygielski, T., Sulej, T., 2016, Revision of the Triassic European turtles Proterochersis and Murrhardtia (Reptilia, Testudinata, Proterochersidae), with the description of new taxa from Poland and Germany: Zoological Journal of the Linnean Society, 177, 395-427.

Tovar, R.E., Montellano, M., 2006, Pleistocene microvertebrates from Santa Cruz Nuevo, Puebla, Mexico: Current Research in the Pleistocene, 23, 72-74.

Tovar, R.E., Montellano-Ballesteros, M., Corona-M., E., 2007, Fauna pleistocénica de Santa Cruz Nuevo, Puebla, México, in Díaz-Martínez, E., Rábano, I. (eds.), 4th European Meeting on the Palaeontology and Stratigraphy of Latin America: Madrid, Cuadernos del Museo Geominero, no ${ }^{\circ}$, Instituto Geológico y Minero de España, 393-397.

Turvey, S.T., Almonte, J., Hansford, J., Scofield, R.P., Brocca, J.L., Chapman, S.D., 2017, A new species of extinct late Quaternary giant tortoise from Hispaniola: Zootaxa, 4277(1), 1-16.
Upchurch Jr, G.R., Otto-Bliesner, B.L., Scotese, C., 1998, Vegetation-atmosphere interactions and their role in global warming during the latest Cretaceous: Philosophical Transactions of the Royal Society of London, 353, 97-112.

Van Devender, T.R., Rea, A.M., Smith, M.L., 1985, The Sangamon interglacial vertebrate fauna from Rancho la Brisca, Sonora, Mexico: Transactions of the San Diego Society of Natural History, 21(2), 23-55.

Vlachos, E., 2018, A review of the fossil record of North American turtles of the Clade Pan-Testudinoidea: Bulletin of the Peabody Museum of Natural History, 59(1), 3-94.

Webb, S.D., Perrigo, S.C., 1984, Late Cenozoic vertebrates from Honduras and El Salvador: Journal of Vertebrate Paleontology, 4(2), 237-254.

Wiens, J.J., Kuczynski, C.A., Stephens, P.R., 2010, Discordant mitochondrial and nuclear gene phylogenies in emydid turtles: implications for speciation and conservation: Biological Journal of the Linnean Society, 99, 445-461.

White, R.S., Mead, J.I., Baez, A., Swift, S.L., 2010, Localidades de vertebrados fósiles del Neógeno (Mioceno, Plioceno y Pleistoceno): una evaluación preliminar de la biodiversidad del pasado, in Molina-Freaner, F.E., Van Devender, T.R. (eds.), Diversidad biológica de Sonora: Mexico, Universidad Nacional Autónoma de México, 51-72.

Williams, E.E., 1950, Testudo cubensis and the evolution of Western Hemisphere tortoises: American Museum of Natural History Bulletin, 95, 1-36.

Williams, E.E., 1952, A new fossil tortoise from Mona Island, West Indies, and a tentative arrangement of the tortoises of the World: Bulletin of the American Museum of Natural History, 99(9), 541-560.

Wood, R.C., 1972, A fossil pelomedusid turtle from Puerto Rico: Breviora, 392, 1-13.

Wrigth, E.K., 1987, Stratification and paleocirculation of the Late Cretaceous Western Interior Seaway of North America: Geological Society of America Bulletin, 99, 480-490.

Manuscript received: june 10, 2020

Corrected manuscript received: october 12, 2020

Accepted manuscript: october 13, 2020 